\title{
НАУЧНО-ОРГАНИЗАЦИОННАЯ РОЛЬ И НАСЛЕДИЕ А. В. АНДРЕЕВА В РАЗВИТИИ ОРНИТОЛОГИЧЕСКИХ ИССЛЕДОВАНИЙ И ОХРАНЕ ПРИРОДЫ СЕВЕРО-ВОСТОКА АЗИИ
}

\author{
Кондратьев А. В., Хаменкова Е. В. \\ ФГБУН Институт биологических проблем Севера ДВО РАН, г. Магадан \\ E-mail: akondratyev@ibpn.ru, ac_secretary@ibpn.ru
}

\begin{abstract}
Представлен анализ научной и научно-организационной деятельности А. В. Андреева как лидера орнитологических исследований на Северо-Востоке России. Дана характеристика его вклада в организацию и развитие природоохранной деятельности в регионе. Работа проиллюстрирована не публиковавшимися ранее фотографиями. Приведен список основных научных работ А. В. Андреева с 1971 г.
\end{abstract}

Ключевые слова: А. В. Андреев, орнитология, птицы, Северо-Восток Азии, Магадан, ИБПС ДВО РАН.

DOI: $10.34078 / 1814-0998-2021-4-5-22$

Александр Владимирович Андреев - доктор биологических наук, заведующий лабораторией орнитологии Института биологических проблем Севера ДВО РАН, автор многих статей и монографий, признанный специалист мирового уровня в области экологической энергетики, экологии, поведения, ландшафтно-экологического распространения и охраны птиц, организатор многопланового изучения птиц Арктики и Дальнего Востока. Невозможно переоценить его роль в изучении и охране природы Северо-Востока России. Вся жизнь и основная научная деятельность Александра Владимировича были связаны с Северо-Востоком Азии, Магаданом и Институтом биологических проблем Севера ДВО РАН.

\section{НАЧАЛО ПУТИ}

Александр Владимирович родился 12 ноября 1948 г. в Ленинграде. Интерес к биологии проснулся в нем в детстве, когда в возрасте 13 лет он пришел в гидробиологический кружок при Ленинградском Доме пионеров в Аничковом дворце, которым руководила Татьяна Георгиевна Жадина. Позднее, в 1962 г., он перешел в кружок охотников-следопытов к Модесту Владимировичу Калинину, другу Алексея Сергеевича Мальчевского, руководившего в тот период кафедрой зоологии позвоночных Ленинградского государственного университета им. А. А. Жданова (ныне - Санкт-Петербургский государственный университет). В 1966 г. с серебряной медалью окончил школу № 188 и поступил на биологопочвенный факультет ЛГУ им. А. А. Жданова. После второго курса, без колебаний, своей научной специализацией выбрал зоологию, поступив на кафедру зоологии позвоночных животных к

(C) Кондратьев А. В., Хаменкова Е. В., 2021 самому А. С. Мальчевскому. Позднее Александр Владимирович напишет: «Моя профессиональная биологическая карьера вышла из стен Аничкова дворца» (личные архивы семьи).

А. В. Андреев практически с самого начала студенчества стал интересоваться дальними экспедициями и Северо-Востоком Азии. Важную роль в его работе сыграла экспедиция на Командорские острова, состоявшаяся на втором курсе университета в мае - сентябре 1969 г. Результатом ее стала курсовая работа «К орнитофауне островов Медного и Топоркова (Командорские острова)» (1970).

В формировании научных интересов А. В. Андреева, помимо А. С. Мальчевского, большую роль сыграл Роальд Леонидович Потапов (19332018) - сотрудник Зоологического музея Зоологического института АН СССР, крупнейший специалист в СССР по тетеревиным птицам. Роальд Леонидович увлек начинающего орнитолога А. В. Андреева изучением экологии тетеревиных. Именно его Александр Владимирович считал своим учителем в науке и с благодарностью вспоминал всю жизнь. Тетеревиным птицам была посвящена и дипломная работа Александра Владимировича, которая называлась «Материалы по зимней экологии тетеревиных птиц по наблюдениям в Ленобласти и Новгородской области». Ее руководителями значились А. С. Мальчевский и Р. Л. Потапов. По результатам защиты, состоявшейся в 1971 г., работа была оценена комиссией на 5 с плюсом.

\section{ПЕРВЫЕ ГОДЫ НА СЕВЕРО-ВОСТОКЕ АЗИИ}

Будучи студентом, Александр Владимирович познакомился с Арсением Васильевичем Кречмаром, известным орнитологом, в тот период работавшим на Северо-Востоке и принимавшим 
активное участие в создании нового института биологического профиля в Магадане (Институт биологических проблем Севера). Арсений Васильевич пригласил А. В. Андреева после окончания университета приехать работать в Магадан. Александр Владимирович с радостью согласился, он надеялся изучать адаптации птиц к экстремальным условиям, и работа на Северо-Востоке лучше всего отвечала его потребностям в этом направлении.

Некоторую «злую шутку» сыграла его успешная работа на Командорских островах. Специалисты, с кем он там работал, способствовали тому, что в ЛГУ на студента А. В. Андреева пришли два запроса на распределение. Магаданский оказался вторым, первым был запрос из Биологопочвенного Института (г. Владивосток) от Николая Николаевича Воронцова. Александр Владимирович во Владивосток ехать не хотел, говорил, что заинтересован в том, чтобы ехать в Магадан, но в университете были непреклонны. «На Вас пришли целых два запроса, а на кого-то - ни одного. Поедете во Владивосток, тут и думать не о чем», - говорили в университете.

По приезде во Владивосток он пошел разговаривать лично с Николаем Николаевичем Воронцовым. Н. Н. Воронцов - выдающийся 3оолог, генетик, эколог, в период с 1970 по 1977 г. руководил Биолого-почвенным институтом. А. В. Андреев рассказал Воронцову, что мечтает заниматься изучением экологии птиц в экстремальных условиях и что с такой темой нет никакого смысла работать во Владивостоке, и что орнитологи в Магадане его очень ждут. Н. Н. Воронцов выслушал Александра Владимировича и отпустил пытливого студента на Север в Магадан.

В 1971 г. его приняли на должность старшего лаборанта с высшим образованием в лабораторию зоологии при отделе биологических проблем Севера в Северо-Восточном комплексном научно-исследовательском институте ДВНЦ РАН (с 01 февраля 1972 г. - Институт биологических проблем Севера ДВНЦ РАН). Уже в 1973 г. он поступил в очную аспирантуру при Институте, которую успешно окончил с представлением диссертации 8 января 1977 г. Руководителями работы были А. С. Мальчевский и А. В. Кречмар, который в то время возглавлял образованную в 1974 г. лабораторию орнитологии.

С самого начала научной деятельности А. В. Андреев проявил себя не только как скрупулезный и увлеченный ученый, но и как человек, обладающий удивительными способностями к выживанию в самых непростых условиях северовосточной тайги. Уже в декабре 1971 - январе 1976 г. он провел сложнейшие исследования по зимней экологии птиц Северо-Востока Азии. От ежедневных тщательных наблюдений при температурах далеко за $-50{ }^{\circ} \mathrm{C}$ он перешел к разработке новых методик и инструментов и проведению остроумных полевых экспериментов, позволи- вших определить калорийность питания птиц, их морфофункциональные особенности, суточный бюджет времени, скорость движения при кормлении и многое другое. В итоге ему удалось собрать уникальные данные по экологии и биоэнергетике 13 видов тетеревиных и воробьиных птиц. В частности - по энергии существования каменного глухаря, белой и тундряной куропаток, рябчика при $-40{ }^{\circ} \mathrm{C}$ (Андреев, 1980). Отдельные публикации этого периода посвящены радиотелеметрическому изучению микроклимата снежных убежищ рябчика (Андреев, Кречмар, 1976), количеству энергии, затрачиваемому каменным глухарем на добывание корма (Андреев, 1975), биоэнергетике кедровки (Андреев, 1977), энергетическому балансу и впервые описанному явлению гипотермии у кукши (Андреев, 1978).

Успехи в изучении жизни птиц в экстремальных условиях принесли А. В. Андрееву выдающиеся результаты и позволили защитить 24 марта 1977 г. в Ленинградском государственном университете кандидатскую диссертацию «Адаптация птиц к зимним условиям Субарктики (крайний северо-восток Сибири)». Оппонентами были доктора наук, профессора Г. А. Новиков и Н. Н. Данилов (Свердловск), ведущим учреждением - Зоологический институт АН СССР.

В 1980 г. по итогам этой работы вышла одноименная с кандидатской диссертацией книга А. В. Андреева, изданная в Москве в издательстве «Наука». В 1981 г. за нее ему была присуждена премия Ленинского комсомола.

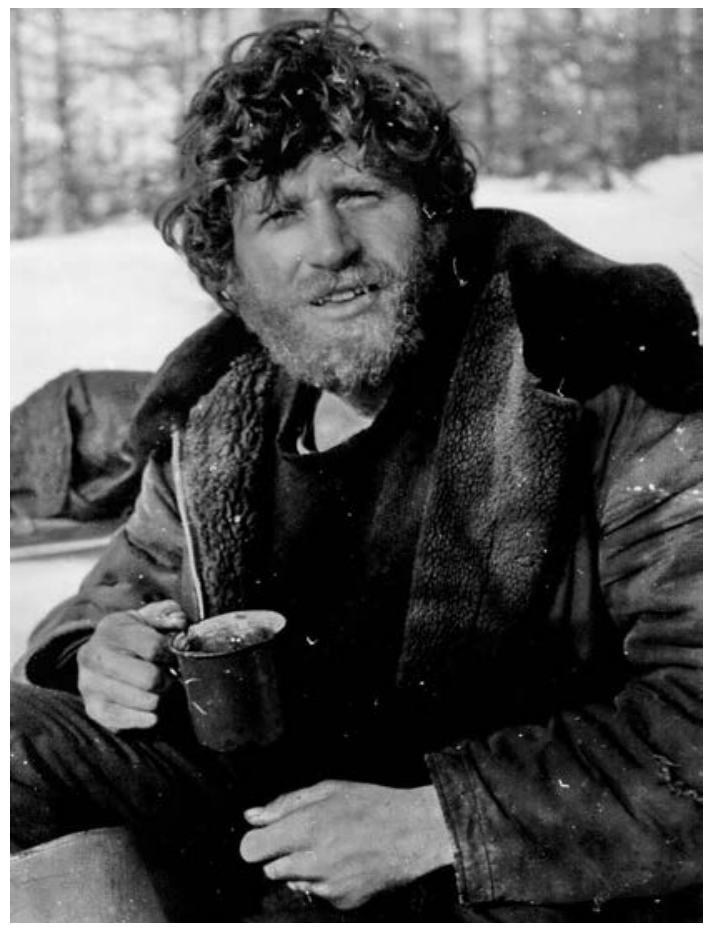

Фото 1. А. В. Андреев на зимних работах на Омолонском стационаре в 1972 г. (фото А. В. Андреева)

Photo 1. A. V. Andreev during his winter research at the Omolon field station in 1972 (Photo by A. V. Andreev) 


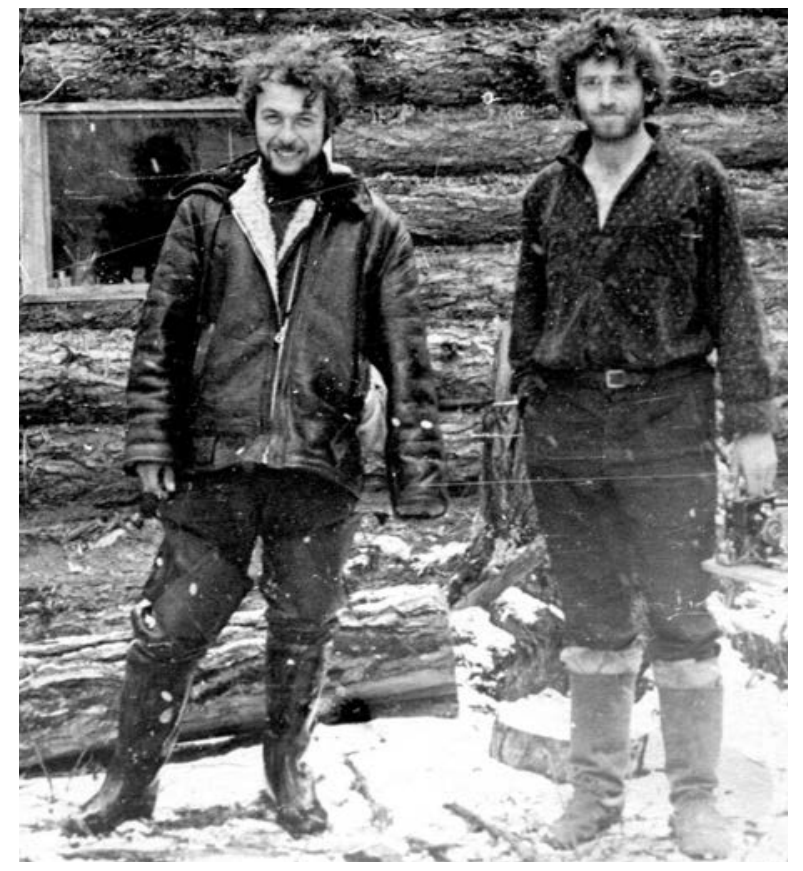

Фото 2. А. В. Андреев и Е. А. Макарченко на р. Омолон. Устье р. Пятьковенде, 1973 г. (фото Е. А. Макарченко)

Photo 2. A. V. Andreev and E. A. Makarchenko on the Omolon River. Pyatkovende River mouth, 1973 (Photo by Ye. A. Makarchenko)

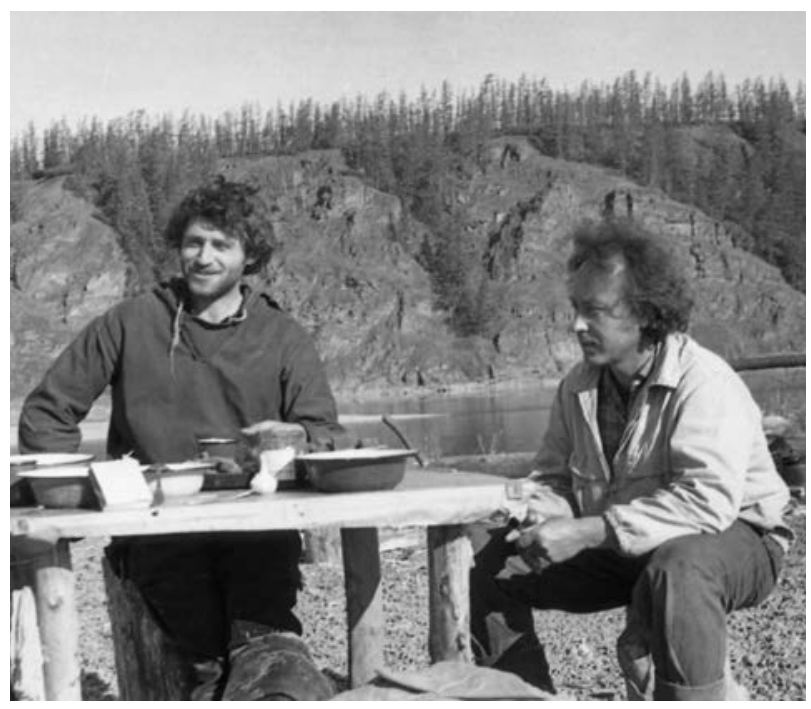

Фото 3. А. В. Андреев и В. М. Постников. Омолон, 1973 г. (фото Е. А. Макарченко)

Photo 3. A. V. Andreev and V. M. Postnikov, Omolon, 1973 (Photo by Ye. A. Makarchenko)

\section{ОСНОВНЫЕ НАПРАВЛЕНИЯ НАУЧНЫХ ТЕМАТИК}

Уже в 1985 г. А. В. Андреев стал исполнять обязанности заведующего лабораторией экспериментальной экологии, а 1 февраля 1989 г. был избран на ее заведование.

Интерес к изучению птиц в экстремальных условиях, возникший в студенчестве, сохранялся главной темой исследований Александра Владимировича многие годы и десятилетия. При этом ключевую роль в возможности получить желаемый результат и ответы на формулируемые вопросы сыграла разрабатываемая им инструментальная база. Многие приборы он полностью конструировал сам. Этой теме посвящено несколько статей методического характера (Андреев, 1984, 1986а, б), а также несколько полученных с использованием этих новых уникальных методик работ, раскрывающих ранее неисследованные аспекты экологии и энергетики арктических птиц в период инкубации (Андреев, 1984) и энергетические требования птенцов арктических птиц в период их роста (Андреев, 1988, 1990).

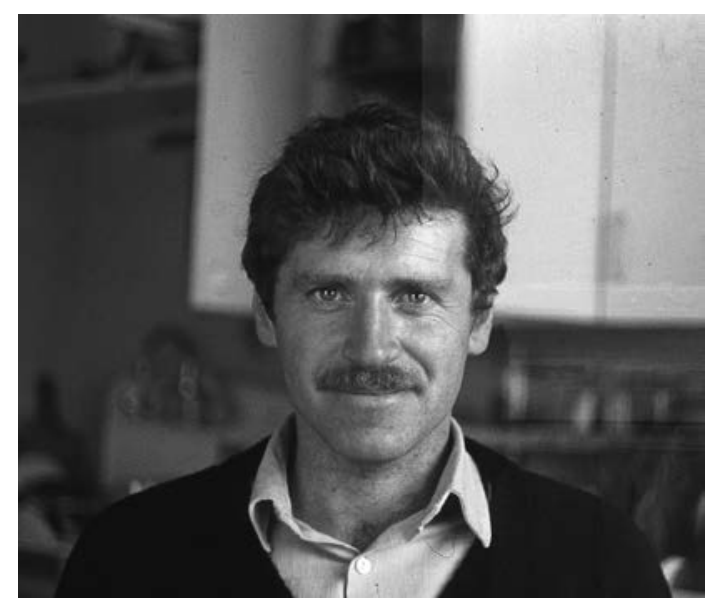

Фото 4. А. В. Андреев - зам. директора ИБПС по науке, 1985 г. (фото Л. В. Соколова)

Photo 4. A. V. Andreev, Vice Director of IBPN, 1985 (Photo by L. V. Sokolov)

В 1990 г. в Зоологическом институте АН СССР (Ленинград) А. В. Андреев защитил докторскую диссертацию на тему «Экологическая энергетика и адаптивные стратегии северных птиц». Его официальными оппонентами были доктор наук В. Р. Дольник (1938-2013), а также два членакорреспондента АН СССР - И. А. Шилов (19212001) и Ю. И. Чернов (1934-2012) из Москвы. Ведущим учреждением выступила кафедра 30ологии позвоночных Ленинградского университета. 21 декабря 1990 г. ему была присуждена степень доктора биологических наук.

Александр Владимирович был глубоким знатоком многих групп птиц. Тем не менее его первой и главной «любовью» в орнитологии всегда были тетеревиные. На основании многолетних популяционно-экологических исследований он опубликовал цикл работ о биологии, зимних адаптациях и причинах десятилетних циклов белой куропатки (Lagopus lagopus) в Нижнеколымских тундрах (Андреев, 1982; Andreev, 1988, 1991, 1994).

Результатом многолетнего мониторинга популяции азиатской дикуши (Falcipennis falcipennis) в 


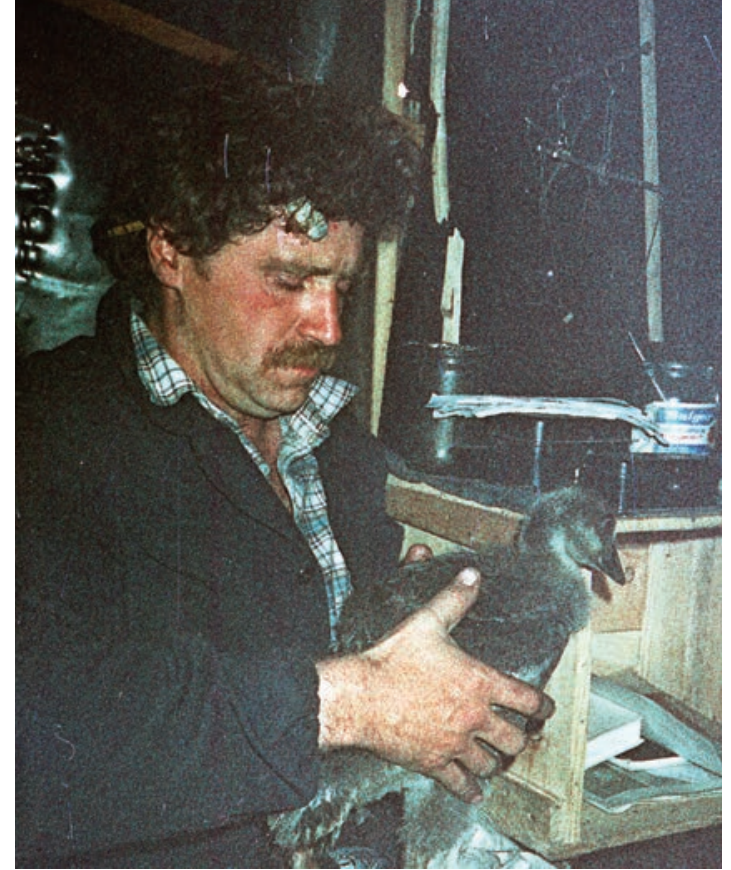

Фото 5. Промеры птенца тундрового гуменника. Нижнеколымские тундры, 1985 г. (фото Е. Р. Потапова)

Photo 5. Measuring a gosling of the Tundra Bean Goose. Kolyma Lowland, 1985 (Photo by Ye. R. Potapov)

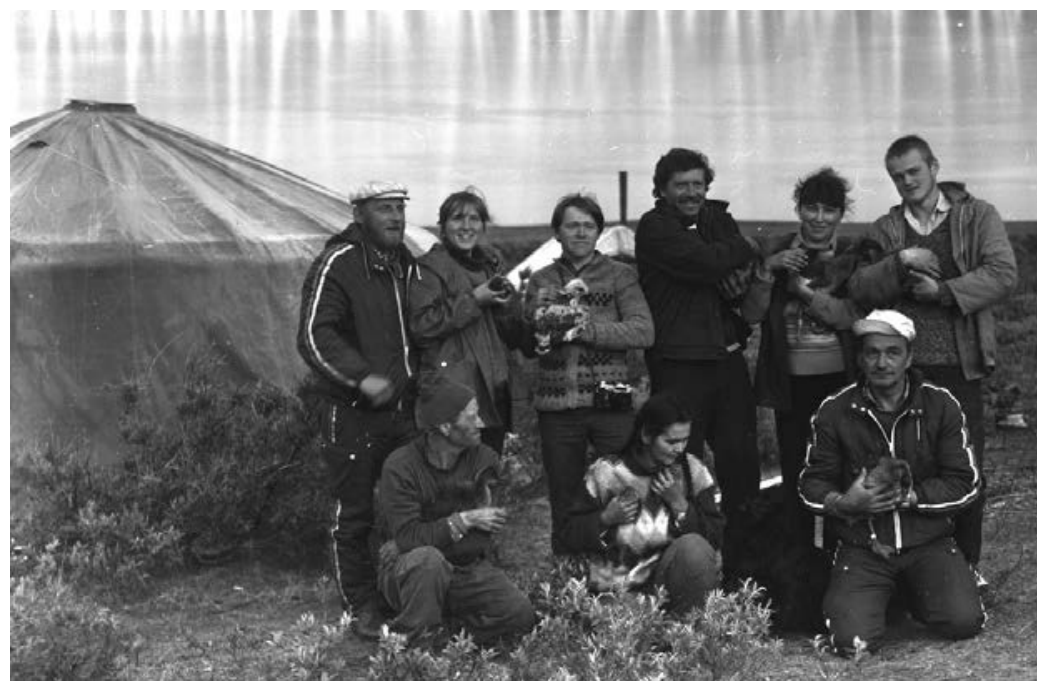

Фото 6. А. В. Андреев с помощниками и коллегами на полевой базе в Нижнеколымских тундрах, 1986 г. (фото Е. Р. Потапова)

Photo 6. A. V. Andreev with his assistants and colleagues at the field station in the Lower Kolyma tundra, 1986 (Photo by Ye. R. Potapov)
Линден, 1986; Klaus et al., 1986). Для наблюдения над токовой и гнездовой жизнью каменного глухаря в разных уголках северо-востока Сибири он строил таежные избушки и закладывал постоянные площадки многолетнего детального, в том числе инструментального, мониторинга. Результаты этих уникальных наблюдений позволили вскрыть многие ранее неизвестные особенности биологии каменного глухаря в разные периоды годового цикла (Андреев, 2015, 2016, 2017).

Интерес Александра Владимировича обращался и к другим группам и видам птиц, расшифровка деталей биологии которых выливалась в уникальные исследования и открытия, приносившие их автору очередное международное признание. Ярким примером могут быть работы по биологии питания, успеха размножения и маршрутам розовой чайки (Rhodostethia rosea) (Андреев, Кондратьев, 1981; Андреев, 1985, 2006; Gilg et al., 2016) или таким редким и малоизученным видам чистиковых, как пыжики - короткоклювый (Brachyramphus brevirostris) и длинноклювый (Brachyramphus perdix) (Андреев, Голубова, 1995; Андреев, 2011, 2018). Специальные работы посвящены также освещению особенностей биологии и стратегий миграции эндемичного вида куликов Северо-Востока Азии - большого песочника (Calidris tenuirostris) (Андреев, 1980, 2010); специальная публикация была посвящена также рыбному филину (Ketupa blakistoni) - редкому виду сов юга Магаданской области (Андреев, 2006).

Не менее пристальное внимание он уделял вопросам биологии арктических гусей - в частности, особенностям их энергетики, распространения, энергетическим потребностям птенцов в период роста, деталям и закономерностям их миграций на Северо-Востоке Азии (Андреев, Дорогой, 1987; Reed, Andreev, 1996; Andreev, 2010). Александр Владимирович занимался проблемами сокращения численности арктических популяций гусей. Организация и проведение в 1990 г. в Магадане Международного совещания по гусям положили начало международному сотрудничеству и целому ряду многолетамурской тайге явилась серия его статей, а также первая в мире монография по биологии этого редкого и малоизученного вида - эндемика Азиатского региона России (Андреев, 1990; Andreev, Hafner, 1998; Andreev et al., 2001; Андреев, 2019).

Объектами не угасающего интереса Александра Владимировича были обыкновенный (Tetrao urogallus) и каменный (Tetrao urogalloides) глухари (Андреев, 1977; Andreev, 1979; Андреев, них работ по мечению гусей и мониторингу их популяций в разных районах на севере Якутии и на Чукотке. Александр Владимирович не только формально руководил этими работами, но и принимал в них самое активное участие. Уже после первых полевых сезонов были получены новые интересные результаты, раскрывающие сложные связи между разными популяциями арктических гусеобразных, зимующих в Китае, Корее, Япо- 
нии и Северной Америке. В 1997 г. он опубликовал первую статью, посвященную инвентаризации популяций гусей в Северо-Восточной Азии (Андреев, 1997). После блестящего доклада на III Международном симпозиуме по гусеобразным птицам в Санкт-Петербурге в 2005 г. Александр Владимирович подготовил всеобъемлющий и глубокий аналитический обзор «Гуси Северо-Восточной Азии: энергетика особей и динамика популяций» (Андреев, 2009).

Помимо исследований экологии и энергетики отдельных видов, Александр Владимирович большое внимание уделял вопросам изучения фауны и распространения птиц, а также выявлению ключевых районов видового разнообразия орнитофауны в различных ландшафтах СевероВостока Азии, неразрывно связывая это с проблемами и задачами охраны не только птиц, но и целых природных комплексов. Результатом фаунистических исследований в пределах северных районов региона явились монографии, написанные в соавторстве с коллегами по лаборатории А. В. Кречмаром и А. Я. Кондратьевым. Это - «Экология и распространение птиц на северо-востоке СССР» (Москва, 1978) и «Птицы северных равнин» (Ленинград, 1991). Обе вышли в издательстве «Наука» и сразу стали библиографической редкостью. В середине 1990-х гг. много внимания было уделено экспедиционному обследованию полуостровов Кони и Пьягина, что позволило получить новые данные о составе орнитофауны и особенностях распределения птиц этого труднодоступного участка северного Приохотья (Andreev, Kondratiev, 2001). Посетив в 2013 г., после почти 30-летнего перерыва, Нижнеколымскую низменность, Александр Владимирович отметил и проанализировал существенные изменения, которые произошли в составе орнитофауны и распространении отдельных видов птиц, в том числе - в связи с происходящими климатическими изменениями (Андреев и др., 2015).

В 1986 г. А. В. Андреев начал долговременные исследования островных коло-

Фото 9. Измерения самки каменного глухаря. А. В. Андреев и Ю. А. Слепцов, полевая база на р. Купка в Омсукчанском районе Магаданской области, 2009 г. (фото Хирото Фукуды)

Photo 9. Measuring the Black-billed Capercaillie female. A. V. Andreev and Yu. A. Sleptsov at the Kupka River field station in the Omsukchan District of Magadan Oblast, 2009 (Photo by Hiroto Fukuda) ниальных морских птиц. Для этого он вместе с А. Я. Кондратьевым организовал долговременную орнитологическую станцию на небольшом о. Талан, расположенном примерно в 100 км от Магадана на западной окраине Тауйской губы в Охотском море.

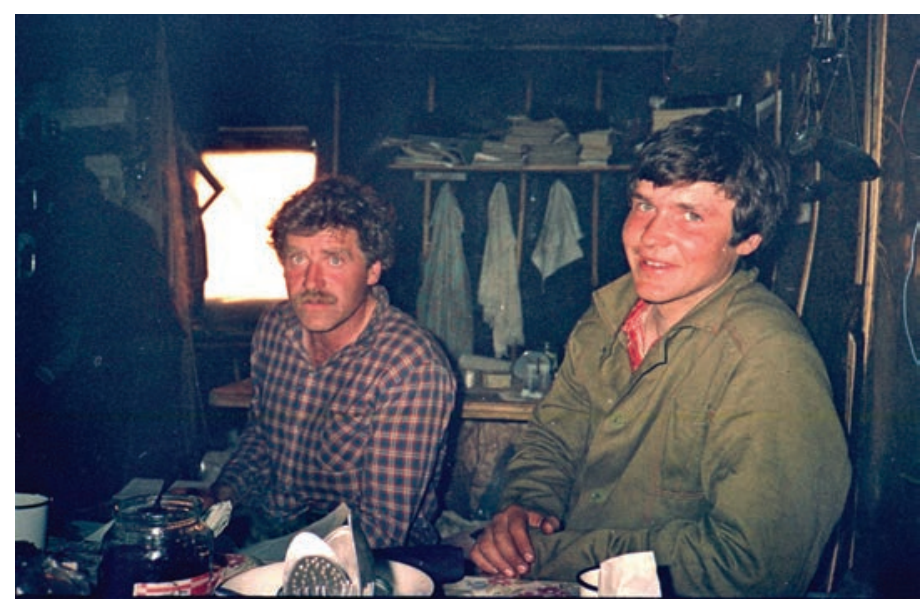

Фото 7. А. В. Андреев и Е. Р. Потапов на полевой базе близ оз. Нерпичье, 1986 г. (фото Е. Р. Потапова)

Photo 7. A. V. Andreev and E. R. Potapov at the field station near Lake Nerpichye, 1986 (Photo by Ye. R. Potapov)

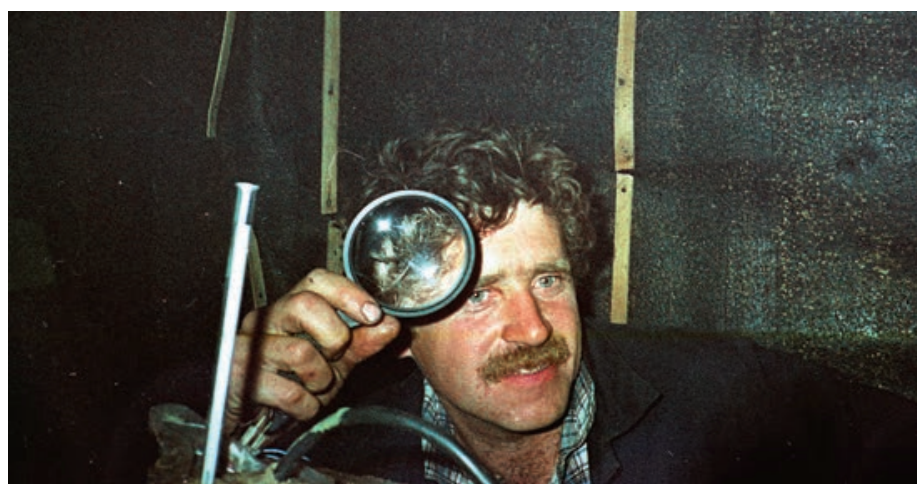

Фото 8. А. В. Андреев на полевой базе на оз. Нерпичье, 1986 г. (фото Е. Р. Потапова)

Photo 8. A. V. Andreev at the Nerpichye Lake field station, 1986 (Photo by Ye. R. Potapov)

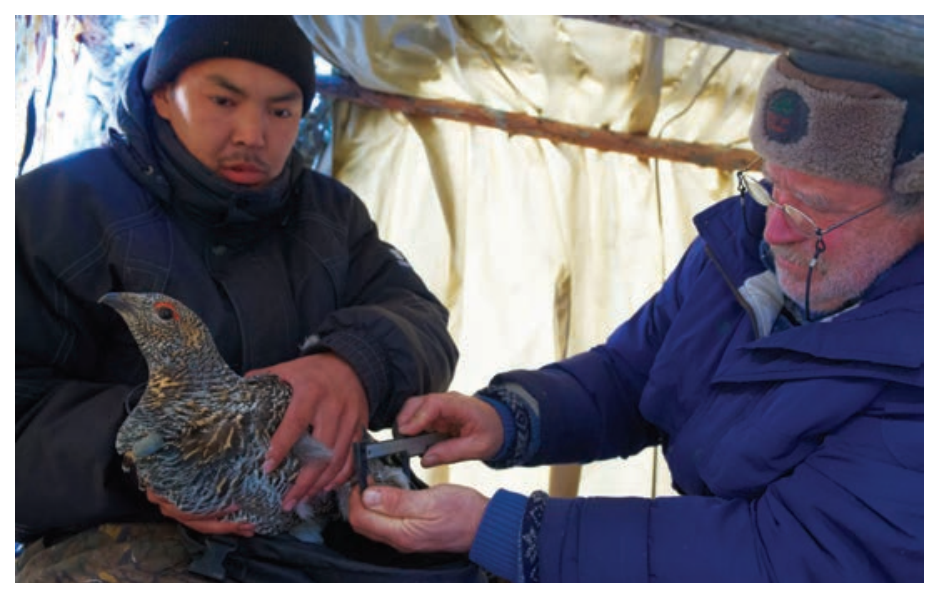




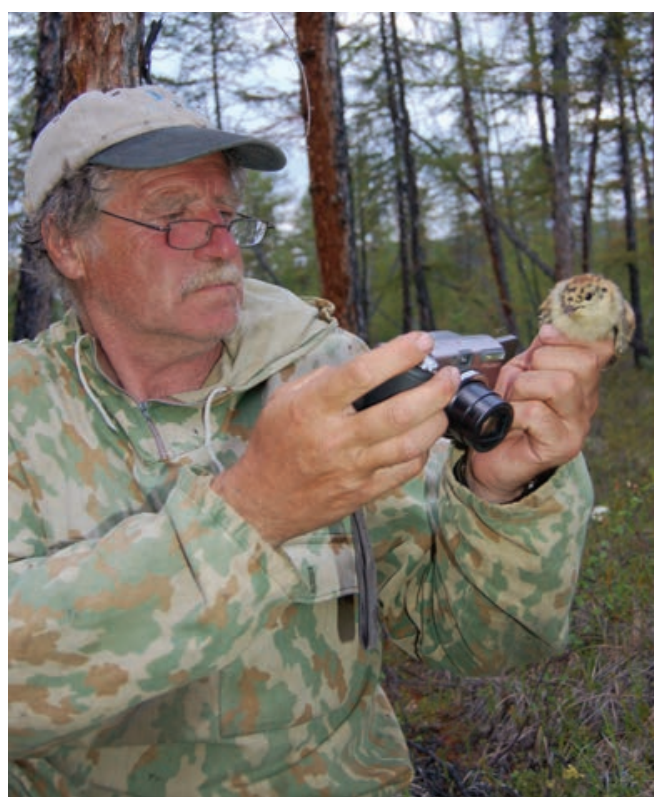

Фото 10. А. В. Андреев с птенцом каменного глухаря. Омсукчанский район Магаданской области, 2008 г. (фото Ю. А. Слепцова)

Photo 10. A. V. Andreev with a Black-billed Capercaillie chick. Omsukchan District of Magadan Oblast, 2008 (Photo by Yu. A. Sleptsov)

В те годы здесь гнездилось около 1 млн птиц. До 1998 г. станцией руководил А. Я. Кондратьев, но после его отъезда из Магадана вся забота о ее поддержании и развитии легла на плечи Александра Владимировича. В начале 90-х гг. о. Талан присвоили статус памятника природы федерального значения, колонии птиц острова охраняются государством. За более чем 30-летнюю историю существования этой станции здесь проводили учеты и исследования коллеги из университетов и институтов России и Аляски, снимали фильмы о биологии морских птиц кинематографисты из Великобритании и Австрии, выполняли дипломные и аспирантские работы студенты и аспиранты университетов Магадана и Москвы (Андреев и др., 2002, 2010, 2012; Андреев, Слепцов, 2013; Андреев, 2016; Андреев, Голубова, 2018, 2019).

С 2011 г., находясь уже в зрелом возрасте, Александр Владимирович увлекся практическим изучением птиц и природы далеких Гималаев и Тибета, приняв участие в 1-й Западно-Гималайской комплексной биогеографической экспедиции Санкт-Петербургского союза ученых, СПбСУ (штат Химачал-Прадеш, Индия). Весной 2013 г. он с коллегами по СПбСУ обследовал засушливый запад Индии (штаты Уттар-Прадеш, Гуджарат, Раджастхан) между Аравийским побережьем Индийского океана и знаменитой пустыней Тар, которую относят к Палеарктике. В 2014 г. он стал одним из учредителей Центра гималайских научных исследований СПбСУ. Одной из главных задач Гималайского проекта были поиски южной

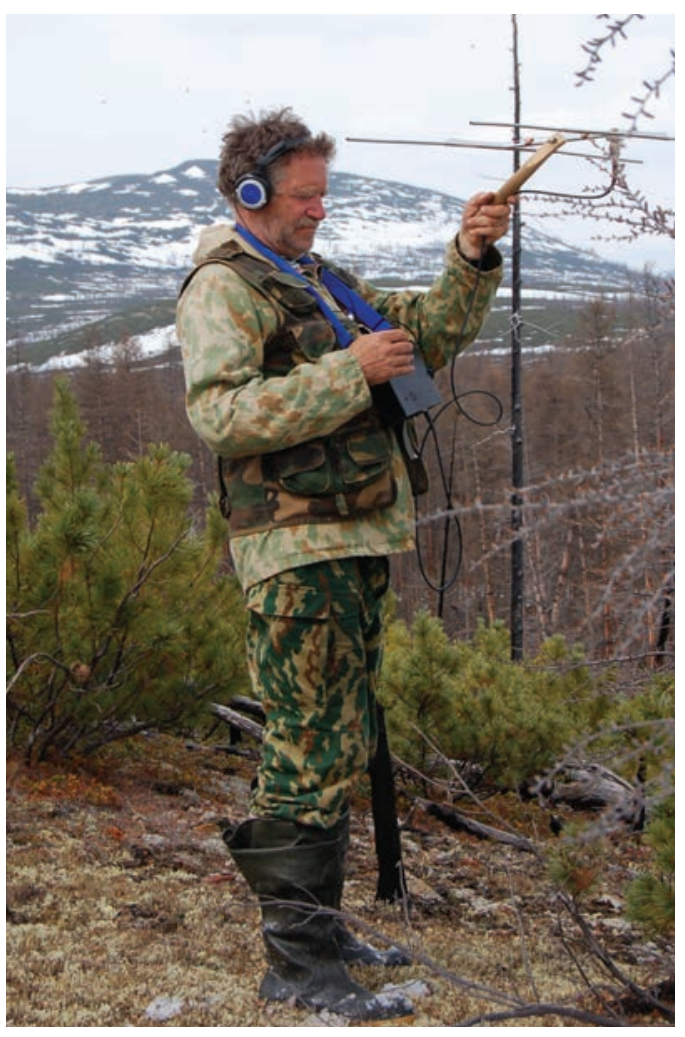

Фото 11. А. В. Андреев с радиопеленгатором во время работ по изучению каменного глухаря. Омсукчанский район Магаданской области, р. Купка, 2008 г. (фото Ю. А. Слепцова)

Photo 11. A. V. Andreev performing radio-tracking during the Capercaillie research. Omsukchan District of Magadan Oblast, 2008 (Photo by Yu. A. Sleptsov)

границы Палеарктики и выявление особенностей распространения палеарктических видов на южном макросклоне Гималаев. Так крайний север и крайний юг Палеарктики соединились в его полевых исследованиях.

Будучи с самого начала научной деятельности, в первую очередь, полевым исследователем, Александр Владимирович очень много времени проводил в экспедициях. География его исследований только на Северо-Востоке включает стационарные работы на Омолоне, в Нижнеколымских тундрах, Чаунской губе, Анадырском заливе, а также в разных точках северного Охотоморья на о. Талан, в зал. Бабушкина, в устье Малкачана. Постоянные наблюдения за биологией каменного глухаря проведены на основе построенных в тайге полевых баз на р. Омчик под Магаданом и на р. Купка в Омсукчанском районе. Маршрутами сплавов покрыты практически весь Омолон и Колыма, многие реки Приохотья, морскими экспедициями - о. Ионы, зал. Шелихова и побережье п-ова Тайгонос, Шантарские острова.

Все свои экспедиции он сопровождал тщательнейшими поденными записями, каждая его поездка была подробно отражена в дневниках. 


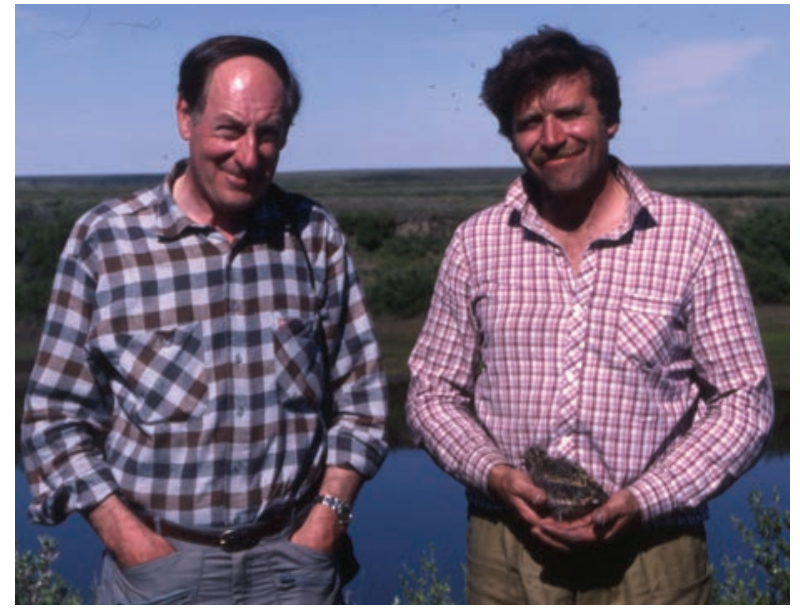

Фото 12. А. В. Андреев с птенцом розовой чайки и британский орнитолог Майкл Денсли (автор книги о розовой чайке в Сибири) в Нижнеколымской тундре, 1992 г. (фото Е. Р. Потапова)

Photo 12. British ornithologist Michael Densley (author of "In Search of Ross's Gull") and A. V. Andreev with a Ross's Gull chick in the Lower Kolyma tundra, 1992 (Photo by Ye. R. Potapov)

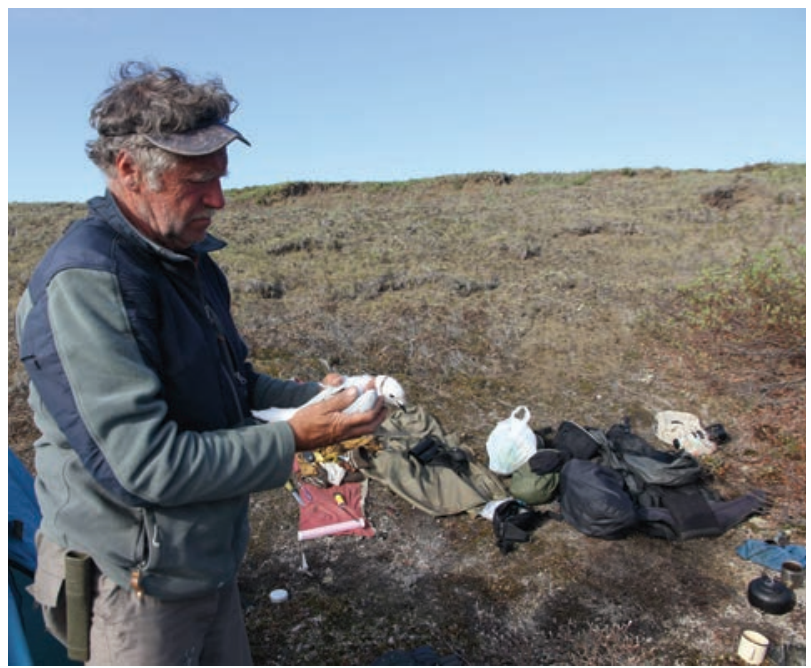

Фото 13. А. В. Андреев с помеченной спутниковым передатчиком розовой чайкой в Нижнеколымской тундре, 2013 г. (фото А. В. Кондратьева)

Photo 13. A. V. Andreev with a Ross's Gull equipped with a satellite transmitter, in the Lower Kolyma tundra, 2013 (Photo by A. V. Kondratyev)

Наряду с профессиональными наблюдениями в этих дневниках отражены коллизии времени, последствия исторических и политических процессов. Примечательно, что свою последнюю экспедицию в 2020 г. он провел, сплавляясь с коллегами именно по Омолону, где в 1972 г., 49 лет назад, начал свои исследования на Северо-Востоке. Записи его последнего полевого экспедиционного дневника пронизывают размышления о современном состоянии некогда развитых поселений (СевероЭвенск, Омолон, Мандриково, Колымское и др.). А сами дневники, помимо научной ценности, являют- ся несомненными литературными свидетельствами исторических событий этой отдаленной земли.

\section{ПРОБЛЕМЫ БЕРИНГИИ}

Все годы своей деятельности А. В. Андреев интересовался исторической зоогеографией Северной Пацифики, пытаясь понять роль Берингии в формировании разнообразия ее орнитофауны (Андреев, 1991, 1997). В 2012 г. он опубликовал ключевую статью под названием «Берингийская орнитология: на пути к новому синтезу», посвященную анализу того, как Берингийская область влияла на эволюцию птиц Голарктики. Как он писал в этой статье, «сначала в течение большей части третичного периода через область сибирско-американской суши шел обмен между орнитофаунами Старого и Нового Света. Затем по мере отступления пояса лесных формаичии к югу в области Берингова пролива формировались разрывы ареалов, приводившие к изоляциии видов на разных континентах и ускорявшие ход дивергенции дендрофильных птиц.

$B$ плейстоцене процесс эволюичи трансберингийских видов определялся множественньми перестройками ландшафтов, возникновением географических барьеров и специирических “берингийских" местообитаний. В это время и сложился комплекс эндемичных берингийских видов и ряда сестринских форм, чьи миграционные трассы вели к областям зимовок на разных континентах. В современную эпоху фаунистический обмен между континентами продолжается, причем преобладает “давление” со стороны Аляски, обусловленное трансформачией криоксерофильньх ландмафтов древней Берингии в озерно-болотныле и кочкарныле тундры.

Новейший процесс, характеризующий состояние берингийской орнитофауны, - замещуение видов, связанных с восточноазиатскими зимовками, близкими североамериканскими видами. По сравнению с другими частями Арктики Берингийская область отличается наиболее высоким видовым разнообразием и обилием птии. Поэтому вопрос о сохранении ее природного наследия имеет приоритетное значение» (Андреев, 2012).

Важную роль в получении данных о существовании у сестринских таксонов птиц, обитающих по обе стороны Берингова пролива, глубокой внутривидовой дифференциации сыграли инициированные и поддержанные А. В. Андреевым работы по сбору генетического материала, выполненные в сотрудничестве с музеем Берка, Вашингтонского университета в городе Сиэтл (The Burke Museum of Natural History and Culture, Seattle, штат Вашингтон, США). Они показали в итоге, что «Берингийская область играла в истории становления орнитофаун гораздо большую роль, нежели просто служила "проходным двором” между континентами, как полагал в свое время Л. А. Портенко (1973)» (Андреев, 2012). 


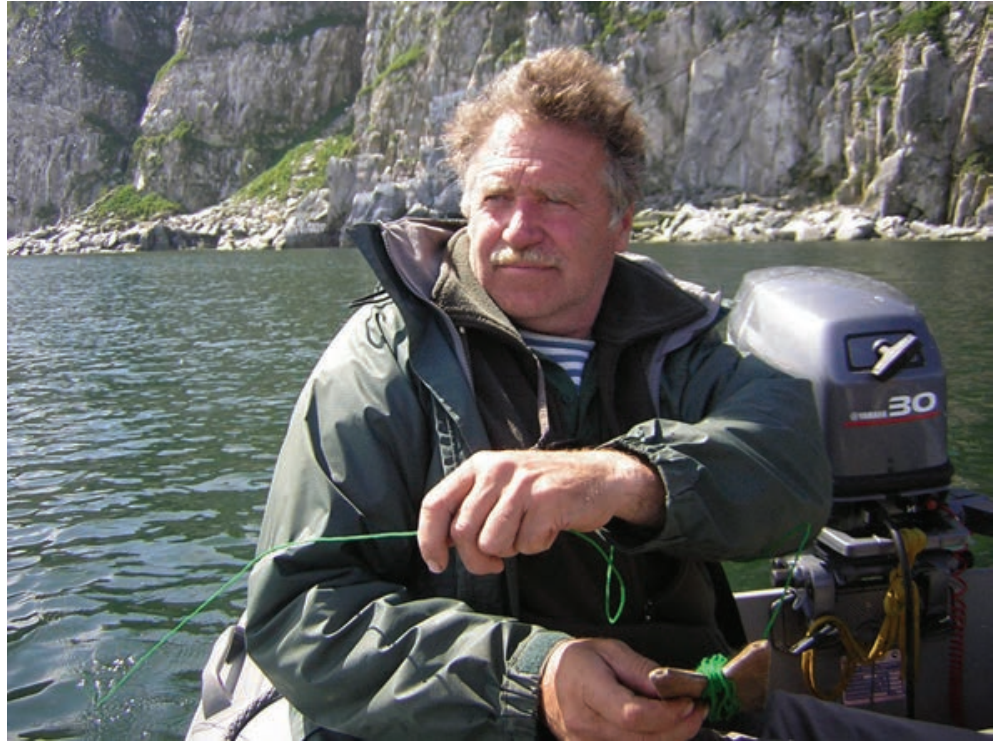

Фото 14. А. В. Андреев во время охотоморских экспедиций. 2007 г. (фото Ю. А. Слепцова)

Photo 14. A. V. Andreev during the Sea of Okhotsk expeditions, 2007 (Photo by Yu. A. Sleptsov)

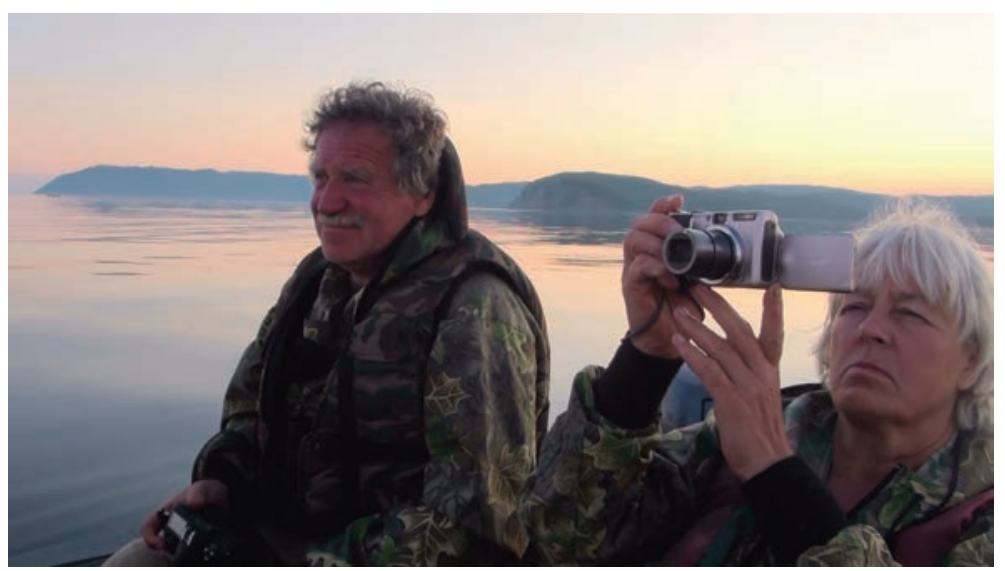

Фото 15. А. В. Андреев и К. В. Регель в Охотском море, 2011 г. (фото А. И. Грачева)

Photo 15. A. V. Andreev and K. V. Regel in the Sea of Okhotsk, 2011 (Photo by A. I. Grachyov)

\section{МЕЖДУНАРОДНОЕ СОТРУДНИЧЕСТВО}

Результаты успешных исследований А. В. Андреева по изучению разнообразия орнитофауны северной части Тихого океана нашли применение в практике российского и международного сотрудничества по охране биологического разнообразия в странах Восточной Азии и регионах Берингова и Охотского морей.

Александр Владимирович был талантливым организатором. Он организовал и провел в Магадане и других городах Сибири и Дальнего Востока целый ряд совещаний высокого ранга. В их числе всесоюзный симпозиум «Изучение и охрана птиц в экосистемах севера» (Магадан, 1986), международная конференция «Популяции диких гусей в северной Азии» (Магадан, 1990; Андреев, Кондратьев, 1991), «Мониторинг восточноазиатских популяций диких гусей» (Благовещенск, 1996).

Международная конференция, посвященная изучению и охране азиатских популяций гусей (Магадан, 1990), послужила долговременному международному сотрудничеству с коллегами из Голландии, Германии, Японии, Южной Кореи и Аляски и созданию цикла совместных работ по изучению распределения и миграций гусей Азиатского континента. Для учетов гусей в тундрах использовалась также авиация, а в масштабных проектах по их отлову и мечению пластиковые ошейники и спутниковые передатчики. За эти исследования Японское общество содействия прогрессу науки наградило Александра Владимировича престижной премией в 1995 г.

Широкое международное признание выразилось также в избрании его в состав ряда престижных международных комитетов и обществ по орнитологии, в том числе членом Международного орнитологического комитета (The International Ornithological Committee, позже - The International Ornithologists' Union), Немецкого общества орнитологов (Die Deutsche OrnithologenGesellschaft, основано в 1850 г.), Комиссии МСОП по выживанию видов (IUCN Species Survival Commission), вице-президентом Азиатского совета BirdLife International (с 1996 г.).

Он являлся членом редколлегии англоязычного журнала «Ornithological Science» (с 2002 г.), выпускаемого Орнитологическим обществом Японии (The Ornithological Society of Japan).

Орнитологическая тематика всегда в той или иной степени направлена на международное взаимодействие. Уже с 1979 г. А. В. Андреев начал выезжать за границу для участия с докладами на различных международных форумах. Его часто приглашали для чтения лекций в Европу, Северную Америку и Азию. Он прекрасно владел английским языком. Понимая значение владения иностранным языком для работы и сотрудничества, уже в возрасте более 40 лет он много внимания уделял изучению английского и его оттачиванию. В постсоветское время зарубежные поездки стали практически ежегодными. Среди стран, где он побывал с научными целями, можно назвать 
Германию (ГДР: 1979, 1981, ФРГ: 1987, 1990, 1996, 1998), Канаду (1982, 1988, 1991), Норвегию (1989), США (Аляска, 1992), Японию (1993, 1995, 2004, 2005), Австрию (1994, 1999, 2001), Великобританию (1994, 1998, 1999), Южную Корею (1995), Малайзию (1995), Индию $(1996,2011,2013$, 2014, 2015, 2017, 2018, 2019), Китай $(2000,2018)$ и Непал $(2018)$.

Созданные Александром Владимировичем или при его участии постоянные и временные стационары и полевые базы почти ежегодно посещались коллегами из Японии, США, Австрии, Германии. Вместе с ними он проводил работы по изучению биологии азиатской дикуши в амурской тайге и рябчика под Магаданом, по отлову и мечению гусей в Анадырских тундрах, по изучению морских птиц на о. Талан, по организации студенческих практик для студентов германских университетов на охотоморском побережье, по съемкам фильмов о природе Северо-Востока и Охотского моря.

\section{НАУЧНО-ОРГАНИЗАЦИОННАЯ ДЕЯТЕЛЬНОСТЬ}

Научную работу А. В. Андреев успешно сочетал с административной, проработав 8 лет (с 1982 по 1985 и с 1992 по 1995 г.) заместителем директора по науке, а с 1991 по 1992 - исполняя обязанности директора института. Тридцать пять лет - с 1985 по 2020 г. - он проработал на посту заведующего лабораторией. Все эти годы он пользовался большим, искренним уважением со стороны сотрудников. Как научный руководитель подготовил большое число орнитологов.

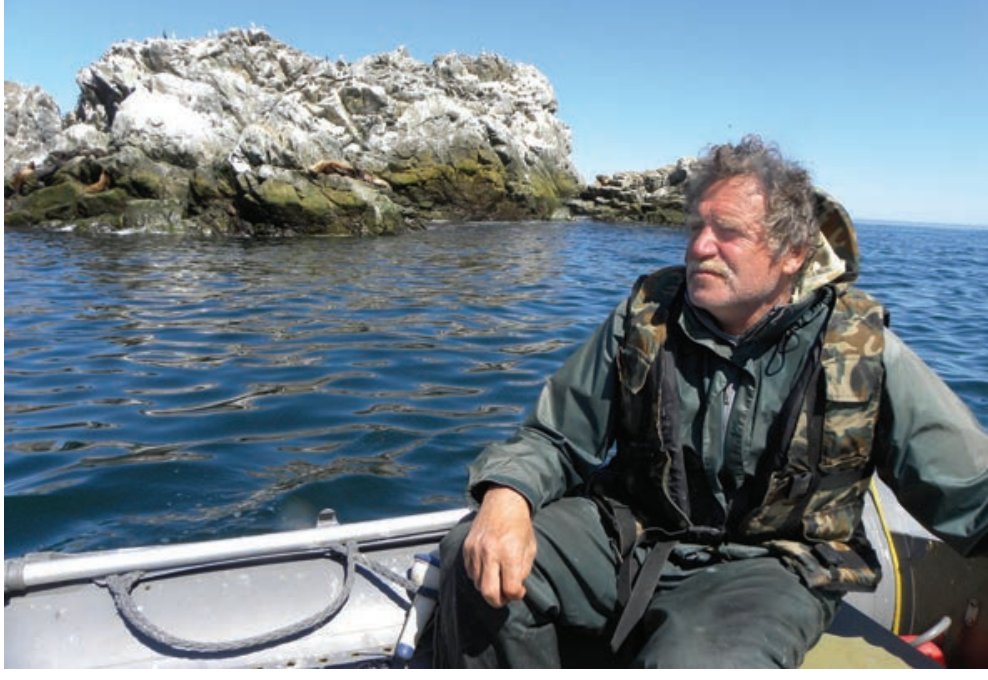

Фото 16. А. В. Андреев обследует Ямские острова, 2009 г. (фото Ю. А. Слепцова)

Photo 16. A. V. Andreev exploring the Yama Islands, 2009 (Photo by Yu. A. Sleptsov)

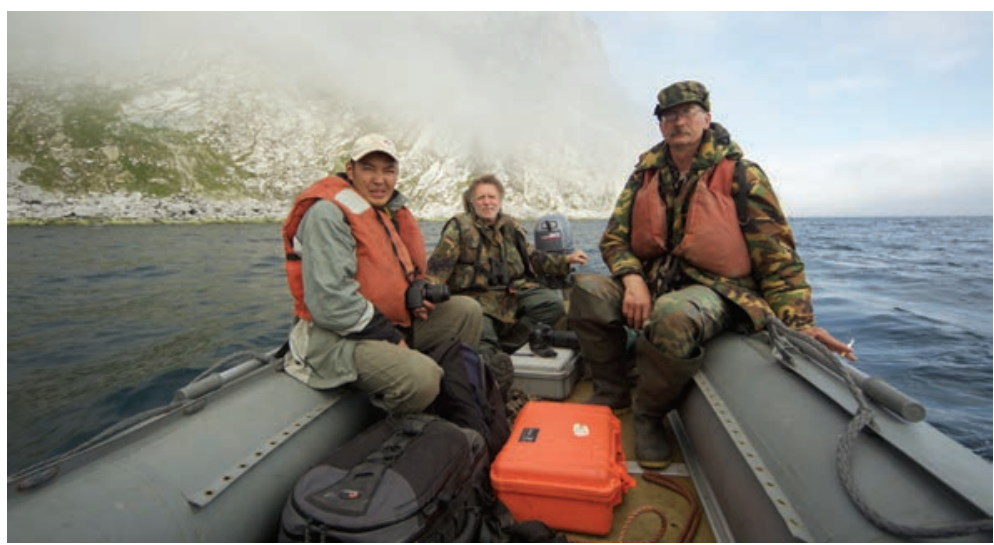

Фото 17. А. В. Андреев, Ю. А. Слепцов и А. И. Грачев обследуют о. Ионы, 2010 г. (фото Найджела Винна)

Photo 17. A. V. Andreev, Yu. A. Sleptsov, and A. I. Grachyov exploring the Iony Island, 2010 (Photo by Nigel Winn)
В начале 1990-х гг. половина молодых сотрудников лаборатории уехали в США, где успешно продолжают работать по специальности, получив там научные степени (В. В. Правосудов, Е. Р. Потапов, А. С. Китайский, С. В. Дровецкий). Среди его магаданских учеников, оставшихся в России, следует назвать кандидатов наук А. В. Кондратьева (1993), И. Г. Утехину (2004) и Е. Ю. Голубову (2007). Будучи руководителем лаборатории орнитологии более 30 лет, Александр Владимирович всегда уделял внимание вопросам и проблемам жизни лаборатории, проблемам жизни и работы всех ее сотрудников. Неутомимый путешественник по своей натуре, он успевал в течение каждого полевого сезона побывать во многих местах, где проводили исследования его коллеги по лаборатории, где-то чтобы помочь организовать и наладить новые на- правления, а где-то и просто помочь в заброске в труднодоступное место.

За долгий период существования лаборатории ее первоочередные задачи менялись. Но среди важнейших, выполнению которых Александр Владимирович как организатор уделял самое пристальное внимание, можно указать: изучение динамики фауны птиц восточного сектора Арктики и процессов ее формирования в историческое время и на современном этапе, многолетний мониторинг численности и репродуктивного успеха морских птиц на островах и побережьях арктических и тихоокеанских морей России, изучение адаптивных стратегий, биологии и состояния популяций птиц Арктики, а также изучение миграционных связей птиц Арктики и Дальнего Востока. 


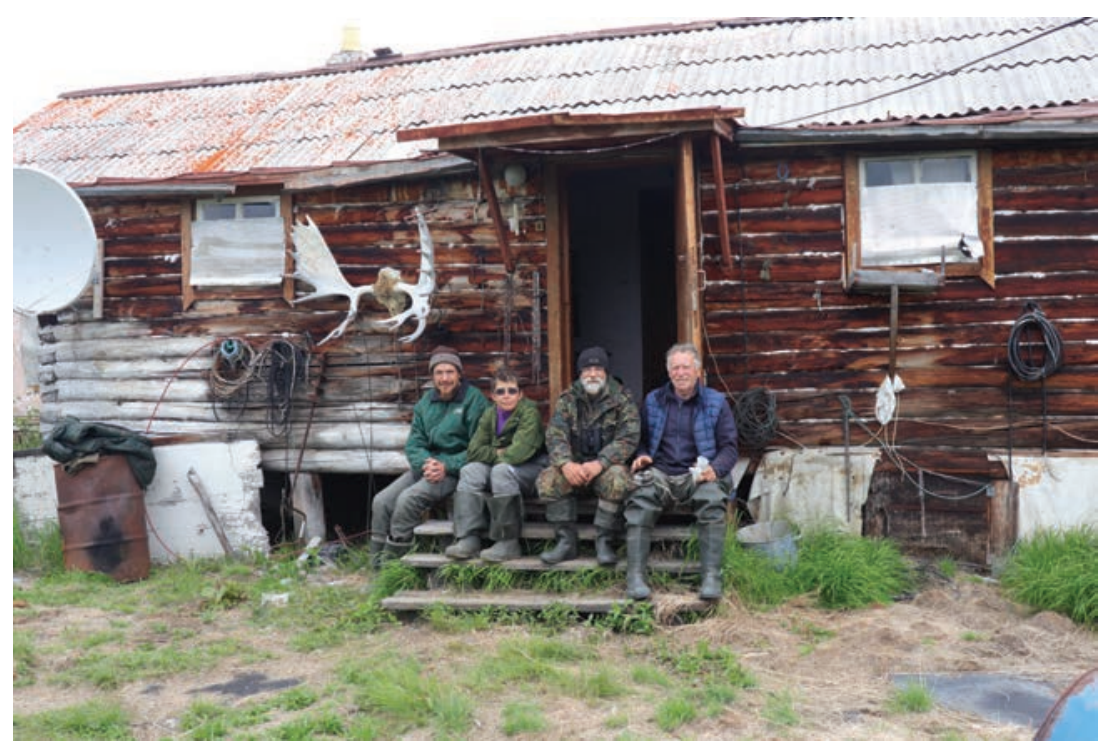

Фото 18. А. В. Андреев с А. А. Бобровым, О. А. Мочаловой и А. В. Кондратьевым на крыльце «Дома для бродяг» - Усть-Олойской метеостанции на р. Омолон, 2020 г. (фото А. В. Кондратьева)

Photo 18. A. V. Andreev with his colleagues (A. A. Bobrov, O. A. Mochalova, and A. V. Kondratyev) on the stairs of the "Traveler's House" at the UstOloy meteorological station on the Omolon River, 2020 (Photo by A. V. Kondratyev)

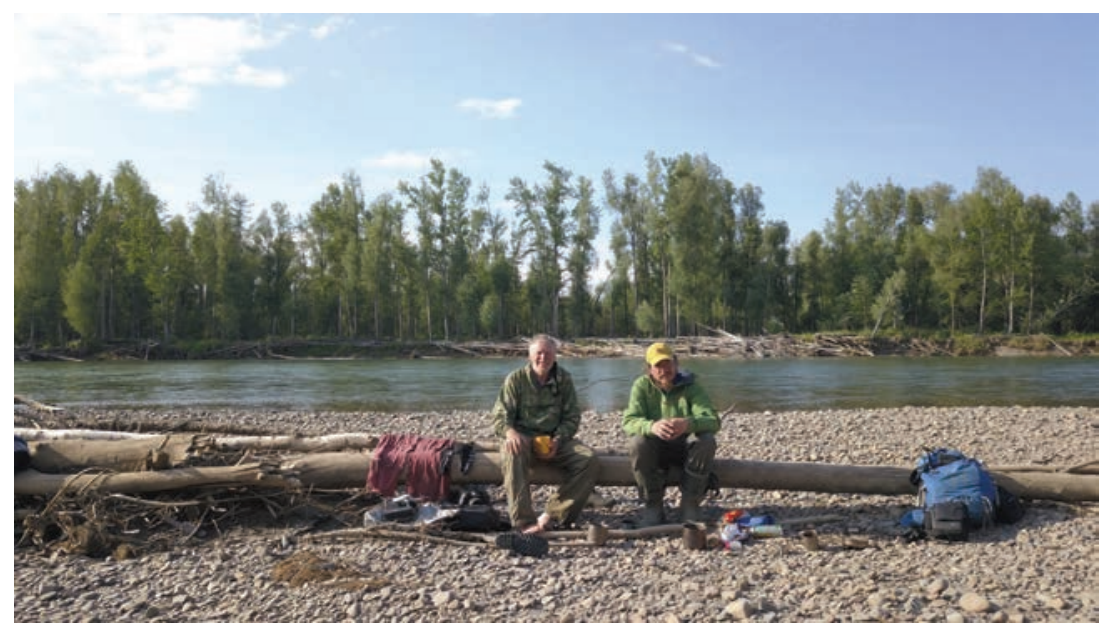

Фото 19. А. В. Андреев и А. А. Бобров в устье р. Пятьковенде, 2020 г. (фото А. В. Кондратьева)

Photo 19. A. V. Andreev and A. A. Bobrov at the Pyatkovende River mouth, 2020 (Photo by A. V. Kondratyev)

Александр Владимирович не только был лидером в каждом из этих направлений, но и собрал вокруг себя круг энтузиастов-единомышленников, активно и успешно работавших по достижению научных результатов в рамках этих задач.

С самого момента основания журнала «Вестник СВНЦ ДВО РАН» в 2005 г. Александр Владимирович входил в состав его редакционной коллегии.

Умея говорить о профессиональных вопросах простым и доступным языком, он был хорошо известен не только среди специ- алистов. С конца 1980-х гг. он был постоянным ведущим передачи «Природа Севера» местного телевидения, очень популярной тогда среди жителей города и области. Он также был снят в трех российских документальных фильмах Это - «Из полевого дневника орнитолога Андреева» (1980), а также два фильма из серии «Страна птиц» Светланы Быченко «Глухариные сады» (2014) и «Розовая чайка» (2021), выпущенных федеральным телевизионным каналом «Культура». Премьера последнего фильма состоялась уже после его смерти.

\section{ОХРАНА ПРИРОДЫ}

Особое внимание Александр Владимирович уделял вопросам сохранения биоразнообразия на Северо-Востоке Азии, а также разработке научных основ охраны природы региона. Для «Красной книги севера Дальнего Востока» (1998), «Красной книги Чукотского автономного округа» (2008) и двух изданий «Красной книги Магаданской области» $(2008,2019)$ А. В. Андреев вместе с коллегами не только подготовил разделы по птицам и млекопитающим, но и входил в состав редакционных коллегий всех этих изданий.

Он организовал и провел кропотливую работу по инвентаризации водно-болотных угодий международного значения на Северо-Востоке России и впервые дал обзор их состояния в регионах дальневосточного севера (Андреев, 2002).

Параллельно с этим им готовились сводки по ключевым орнитологическим территориям Северо-Востока Азии. В 1996 г. А. В. Андреев избран вице-президентом Азиатского совета международного природоохранного общества BirdLife International и вошел в состав редакционной коллегии Красной книги птиц Азии (“Threatened Birds of Asia: The BirdLife International Red Data Book”, 2001).

Александр Владимирович обладал глубоким научным и общекультурным пониманием Севе$\mathrm{pa}$, особенностей жизни здесь живых организмов 
и систем. Его глубоко интересовали вопросы истории освоения и изучения Северо-Востока, много внимания он уделял освещению научного и культурного наследия исследователей северных территорий в начале и середине XX столетия. Специальная публикация была посвящена вкладу А. П. Васьковского в изучение биологического разнообразия и охрану природы Северо-Востока Азии (Андреев, 2007). Задачам охраны природы А. В. Андреев в последние годы уделял все больше и больше времени и сил.

Закономерно, что от вопросов охраны птиц и их важнейших мест обитания, инвентаризацией которых он занимался очень подробно и тщательно (Андреев, 2002, 2005, 2016), интерес и внимание Александра Владимировича сместились к вопросам анализа состояния охраны природы на Северо-

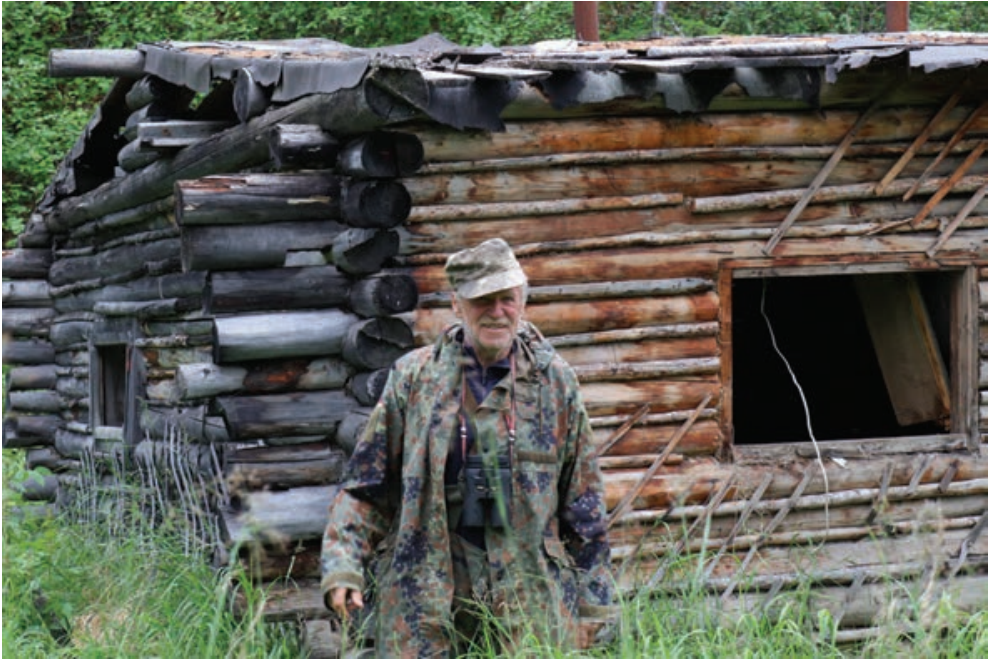

Фото 20. А. В. Андреев близ остатков Омолонского стационара, 2020 г. (фото А. В. Кондратьева)

Photo 20. A. V. Andreev near the Omolon field station remains, 2020 (Photo by A. V. Kondratyev)
Востоке Азии в целом. Он обобщил обширные материалы, касающиеся состояния особо охраняемых природных территорий Магаданской области, и показал, что их сеть находится в ущербном положении и непременно должна быть расширена.

В качестве этапа этого анализа в 2013 г. в Магадане вышла его замечательная монография «Эталоны природы Охотско-Колымского края», которая географически охватывает Магаданскую область, а также прилегающие территории Хабаровского края (Охотский район) и Камчатской области (Пенжинский район). В книге описана история создания особо охраняемых природных территорий различного ранга и анализируется размещение в регионе не только их, но и основных компонентов природного наследия, т. е. редких видов растений и животных, типичных и уникальных ландшафтов, особо ценных природных участков. Александр Владимирович обобщил сведения о формах и степени нарушенности природных экосистем Магаданской области, описал основные угрозы, связанные с человеческой деятельностью. Он также провел анализ участков, еще не имеющих охранного статуса, но важных в отношении сохранения природного разнообразия, и разработал стратегию расширения и развития сети охраняемых природных территорий в Охотско-Колымском регионе, более других страдающем от россыпной золотодобычи.

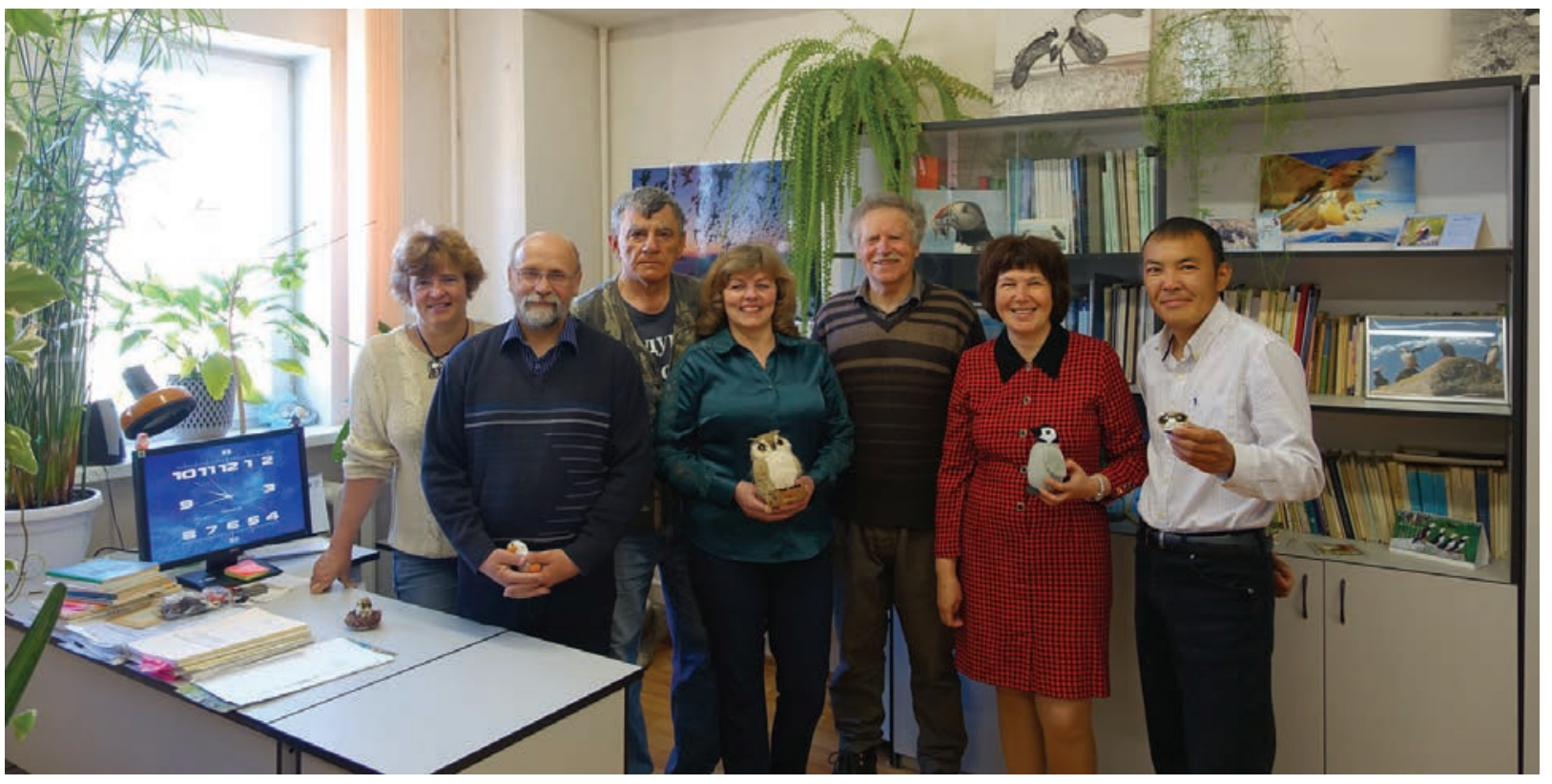

Фото 21. А. В. Андреев среди коллег по лаборатории орнитологии, 2017 г. (фото А. В. Кондратьева)

Photo 21. A. V. Andreev and his colleagues from the Laboratory of Ornithology, 2017 (Photo by A. V. Kondratyev) 


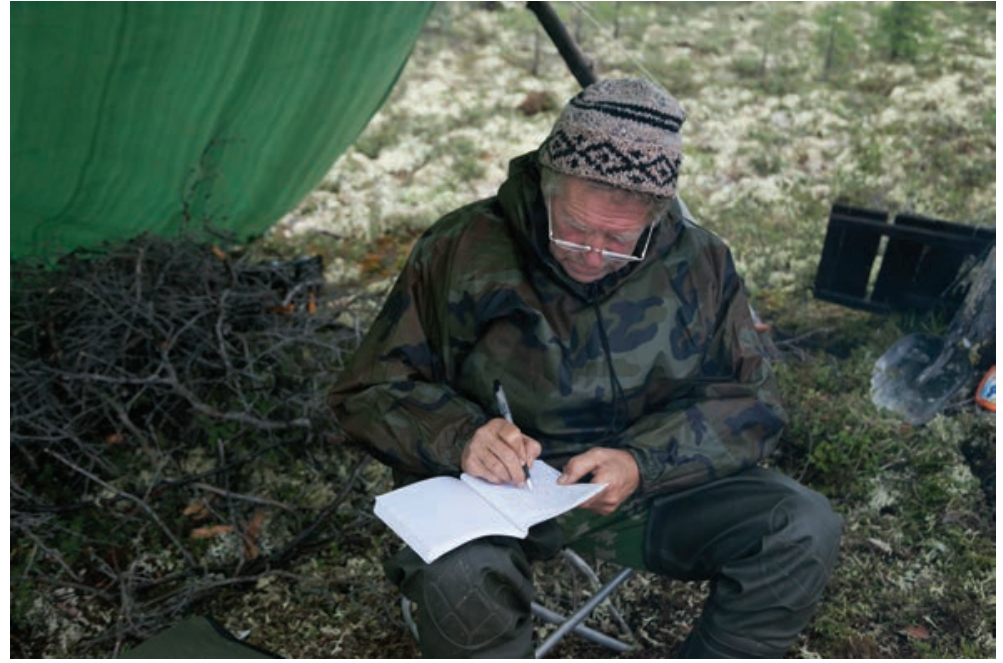

Фото 22. А. В. Андреев заполняет полевой дневник на оз. Дарпир. Экспедиция 2018 г. по обследованию озер Омулевского среднегорья (фото Д. А. Андреевой)

Photo 22. A. V. Andreev writing his daily notes at Lake Darpyr. Expedition of 2018 for exploring lakes in the Omulyovka mountane zone areas (Photo by D. A. Andreeva)

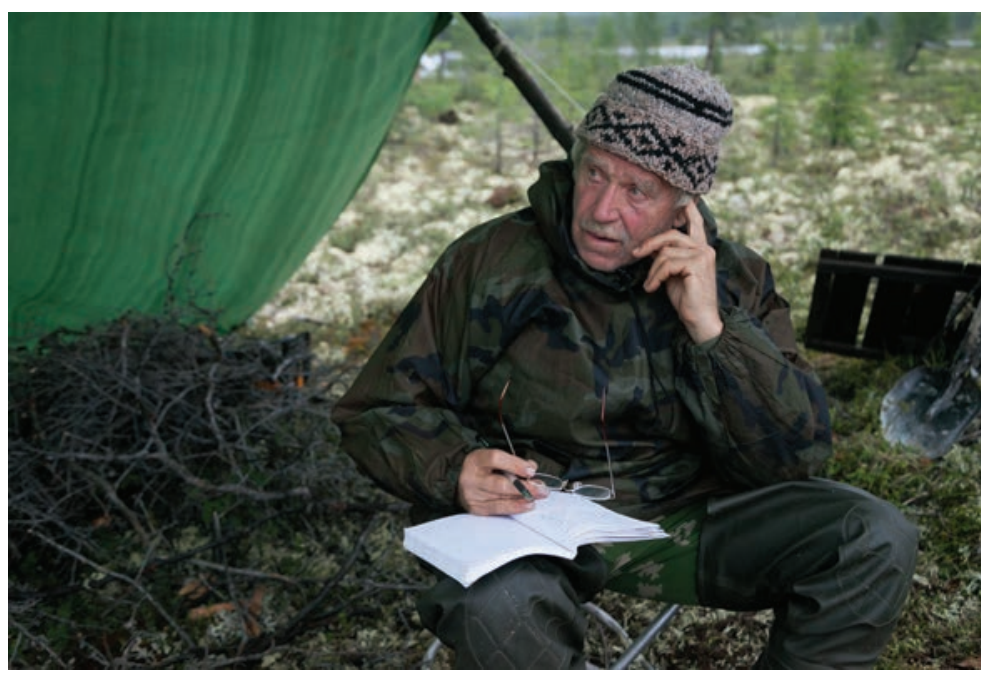

Фото 23. Размышления о создании национального парка. Оз. Дарпир, 2018 г. (фото Д. А. Андреевой)

Photo 23. Thinking about the future National Park. Lake Darpyr, 2018 (Photo by D. A. Andreeva)

Несколько последних лет были посвящены экспедициям в труднодоступные районы уникальных высокогорных озер на границе Магаданской области и Якутии. По итогам этих экспедиций Александром Владимировичем с коллегами была начата подготовка к созданию здесь федерального национального парка «Черский». Значение этой территории для сохранения историкокультурного и природного наследия всего Верхнеколымского бассейна было подробно описано в статье, подготовленной для известного научнопопулярного журнала «Природа» (Андреев и др., 2020). С большими надеждами по этому вопросу он улетал из Магадана в сентябре 2020 г. и, до того как болезнь успела себя проявить, провел важные переговоры и встречи в Министерстве природных ресурсов и экологии РФ, где смог объяснить важность и значение этой работы.

Александр Владимирович был не только крупным ученым и организатором. Он был и талантливым писателем, фотографом и художником. И в многогранной творческой деятельности его любимыми объектами, конечно же, были птицы. На большинстве сделанных им рисунков и фотографий - не статичные портреты, а вовремя и удачно «подсмотренные» в естественной для них обстановке животные, позы которых могут поведать много интересного об их поведении. Прекрасный рассказчик, он всегда с удовольствием делился своими глубокими знаниями не только в орнитологии, но и в вопросах этнографии и истории арктических исследований.

Торопясь жить, он был полон планов, старался вновь и вновь побывать на любимом острове Талан, в построенных им на глухариных токах домиках, особенно на излюбленном месте - ручье Омчик под Магаданом, открывал для себя новые места - от труднодостуных озер в южных отрогах хр. Черского до Гималайских гор.

Друзья и коллеги всегда высоко ценили его целеустремленность и широкий взгляд на явления природы, приверженность лучшим идеалам, принципиальность, неприятие зла и несправедливости. Он был надежным товарищем, а для многих и образцом для подражания. Для своих коллег и друзей он был не только целеустремленным харизматичным лидером, но и вдохновителем научного творчества и смелого научного поиска. Долгие годы совместной работы и общения с ним оказали огромное влияние на успехи и достижения всех лабораторий института, служили примером служения науке и ее идеалам для многих коллег не только дальневосточного региона, но и всего российского научного сообщества.

Проработав в Магадане 49 лет, Александр Владимирович покинул наш мир, полный творческих замыслов, не успев завершить многие свои планы. 


\section{СПИСОК НАУЧНЫХ ПУБЛИКАЦИЙ АЛЕКСАНДРА ВЛАДИМИРОВИЧА АНДРЕЕВА}

Андреев А. В. Особенности экологии тундряной куропатки (Lagopus mutus) на Командорских островах // Зоологический журнал. 1971. Т. 50, № 8. C. $1260-1262$.

Андреев А. В. Об энергетическом балансе и особенностях пищеварения тетеревиных птиц в зимний период // Биологические проблемы Севера. Магадан : СВКНИИ ДВНЦ АН СССР, 1973. Вып. 2. С. 144-155.

Потапов Р. Л., Андреев А. В. К биоэнергетике тетерева Lyrurus tetrix в зимний период // ДАН СССР. Сер. биол. 1973. Т. 210, № 2. С. 499-500.

Андреев А. В. О путях приспособления тетеревиных птиц к зимним условиям существования // Зоологические исследования Сибири и Дальнего Востока : Материалы V Всесоюз. симпозиума «Биологические проблемы Севера», 1972 г. Магадан - Владивосток, 1974. C.108-111.

Андреев А. В. Зимняя жизнь и питание тундряной куропатки (Lagopus mutus) на крайнем СевероВостоке СССР // Зоологический журнал. 1975. Т. 54, № 5. C. 727-733.

Андреев А. В. О количестве энергии, затрачиваемой каменным глухарем на добывание зимнего корма // Экология. 1975. № 6. С. 90-92.

Андреев А. В., Кречмар А. В. Радиотелеметрическое изучение микроклимата снежных убежищ рябчика - Tetrastes bonasia sibiricus // Зоологический журнал. 1976. Т. 55, № 7. С. 1113-1114.

Андреев A. В. Биоэнергетика кедровки (Nucifraga caryocatactes) в условиях крайне низких температур // Зоологический журнал. 1977. Т. 56, № 10. C. $1578-1581$.

Андреев A. B. Температурные условия в снежных лунках рябчика (Tetrastes bonasia kolymensis) // Экология. 1977. № 5. С. 93-95.

Андреев $A$. В. Токовое поведение каменного глухаря в северо-восточной Сибири // Орнитология. 1977. № 13. С. 110-116.

Кречмар А. В., Андреев А. В., Кондратьев А. В. Экология и распространение птиц на северо-востоке СССР. Москва : Наука, 1978. 195 с.

Андреев А. В. Энергетический баланс и явление гипотермии у кукши в зимний период // Экология. 1978. № 4. C. 66-72.

Андреев А. В. Изучение биоэнергетики тетеревиных птиц, зимующих на северо-востоке Азии // Птицы северо-востока Азии. Владивосток, 1979. С. 79-94.

Андреев А. В. Материалы по биологии тетеревиных птиц северо-восточной Сибири в зимний период // Птицы северо-востока Азии. Владивосток, 1979. C. 27-56.

Андреев A. B. О соотношении между энергетическим балансом и бюджетом времени в экологии северных птиц // ДАН СССР. 1979. Т. 246, № 3. С. 756760.

Andreev A. V. Reproductive behavior in Black-billed Capercaillie compared to Capercaillie // Woodland grouse symp. TWI Lovel. Inverness, 1979. P. 134-139.

Andreev A. $V$. Review of methods and results of grouse bioenergetics in winter // Woodland grouse symp. TWI Lovel. Inverness, 1979. P. 87-91.
Андреев А. В. Адаптации оседлых птиц СевероВосточной Азии к зимним условиям существования // Адаптация животных к зимним условиям. Москва : Наука, 1980. С. 5-11.

Андреев А. В. Адаптация птиц к зимним условиям Субарктики. Москва : Наука,1980. 176 с.

Андреев А. В. К биологии сибирского пепельного улита // Новое в изучении биологии и распространении куликов : Материалы Второго совещания по фауне и экологии куликов (5-7 февр. 1979 г.). Москва : Наука, 1980. С. 128-129.

Андреев А. В. К изучению гнездовой биологии большого песочника // Орнитология. 1980. № 15. С. 207-208.

Андреев А. В., Кондратьев А. Я. Новые данные по биологии розовой чайки (Rodostethia rosea McGill) // Зоологический журнал. 1981. Т. 60, № 3. С. 418-425.

Андреев А. В. Зимняя энергетика и бюджет времени флуктуирующих популяций белой куропатки Lagopus lagopus (L.) на северо-востоке Азии // Бюджеты времени и энергии у птиц в природе. Ленинград, 1982. С. 68-90 (Тр. ЗИН ; т. 113).

Андреев A. В. Особенности зимней экологии кукши и кедровки на крайнем северо-востоке Сибири // Орнитология. 1982. № 17. С. 72-82.

Andreev $A$. $V$. Energy balance and hypothermy in the Siberian Jay during the winter season // Proceedings of the XVII Otnithological Congress. Moscow, 1982.

Andreev A. $V$. Seasonal trends and some features of biology of willow grouse populations in north-east Asia // Proceedings of the 2-nd Grouse Symposium TWI Lovel. Edinburgh, 1982. P. 96-106.

Андреев A. В. Экспериментальное изучение энергетических параметров инкубации у некоторых арктических птиц // ДАН СССР. 1984. Т. 278, № 5. C. 1269-1273.

Андреев А. В. Энергетика особи и видовые адаптивные признаки у тундровых птиц // Адаптация организмов к условиям Крайнего Севера : тез. докл. Всесоюз. совещ. (Таллин, 27-30 ноября 1984 г.). Таллин, 1984. С. 15-20.

Докучаев Н. Е., Андреев А. В., Атрашкевич Г. И. Материалы по распространению и биологии сибирского углозуба, Hynobius keiserlingii, на крайнем северо-востоке Азии // Экология и фаунистика амфибий и рептилий СССР и сопредельных стран. Ленинград, 1984. С. 109-114 (Тр. ЗИН ; т. 124).

Андреев A. B. Успех размножения розовой чайки Rodostethia rosea (McGill) в Нижнеколымской тундре и определяющие его факторы // Редкие и исчезающие птицы Дальнего Востока. Владивосток, 1985. С. 110-131.

Potapov R. L., Andreev A. V. Time and energy budgets of wintering Tetraonidae / Acta XVIII Congressus Internationalis Ornitologici. Moscow : Nauka, 1985. Vol. 1. P. 409-412.

Андреев А. В., Линден Х. Зимняя энергетика глухаря в Лапландии // Актуальные проблемы орнитологии. Москва : Наука, 1986. С. 49-69.

Андреев $A$. В. Инструментальные методы в исследованиях по экологической энергетике птиц // Экспериментальные методы в изучении северных птиц и результаты их применения : сб. науч. тр. Владивосток : ДВНЦ АН СССР, 1986. С. 59-83. 
Андреев A. B. Тепловые потоки в гнездах и энергетика процесса инкубации у тундровых птиц // Экспериментальные методы в изучении северных птиц и результаты их применения : сб. науч. тр. Владивосток : ДВНЦ АН СССР, 1986. С. 84-107.

Фирсова Л. В., Михтарьяни Э. А., Андреев А. В. Фаунистические заметки о некоторых птицах Командорских островов // Распространение и биология птиц Алтая и Дальнего Востока. Ленинград, 1986. С. 89-98 (Тр. ЗИН ; т. 150).

Klaus S., Andreev A., Bergmann H.-H. Die Auerhuhner. Wittenberg-Lutherstadt : A. Ziemsen Verlag, 1986. $276 \mathrm{~s}$.

Андреев А. В., Дорогой И. В. Гнездование белого гуся в тундрах Колымской и Чаунской низменности // Бюллетень МОИП. 1987. Т. 92, № 2. С. 42-44.

Андреев A. В. Пищевые потребности и индивидуальное выживание арктических птенцов // Изучение и охрана птиц в экосистемах севера : сб. науч. тр. Владивосток : ДВО АН СССР, 1988. С. 8-17.

Andreev $A$. $V$. Ecological energetics of Palearctic Tetraonidae in relation to chemical composition and digestibility of their winter diets // Canadian Journal of Zoology. 1988. Vol. 66, No. 6. P. 1382-1390.

Andreev $A$. $V$. The ten years cycle of the willow grouse of Lower Kolyma // Oecologia. 1988. No. 76. P. 261267.

Klaus S., Andreev A., Bergmann H.-H., Muller F., Porkert J., Wiesener J. Die Auerhühner. 2 Aufl. Wittenberg-Lutherstadt: A. Ziemsen Verlag, 1989. $280 \mathrm{s.}$

Андреев A. B. Наблюдения по зимней биологии дикуши (Falcipennis falcipennis) в Приамурье // Зоологический журнал. 1990. Т. 69, № 3. С. 69-80.

Андреев A. В. Экологическая энергетика арктических птенцов // Современная орнитология. Москва : Наука, 1990. С. 5-21.

Chernyavski F. B., Andreev A. V. Studies on the ecology of terrestrial vertebrates in North-East of the USSR and perspectives for international cooperation // Arctic Research, Advances and Prospects, 2. Moscow : Nauka, 1990. P. 186-194.

Андреев А. В., Кондратьев А. В. Международный симпозиум «Популяции диких гусей Северной Азии» // Экология. 1991. № 5. С. 94-96.

Андреев А. В. Сохранить берингийское наследие // Вестник ДВО АН СССР. 1991. № 1. С. 29-41.

Кречмар А. В., Андреев А. В., Кондратьев А. Я. Птицы северных равнин. Ленинград : Наука, 1991. 288 c.

Andreev A. $V$. Winter adaptation in the Willow Ptarmigan // Arctic. 1991. Vol. 44, No. 2. P. 106-114.

Andreev $A$. $V$. Winter habitat segregation in the sexually dimorphic black-billed capercaillie, Tetrao urogalloides // Ornis Scandinavica. 1991. No. 22. P. 287-289.

Андреев A. B. Роль клетчатки и протеина в экологической энергетике белой куропатки в зимний период // Экология. 1992. № 2. С. 56-70.

Фирсова Л. В., Михтарьяни Э. А., Андреев А. В. Материалы по чайкам и чистиковым птицам Командорских островов // Русский орнитологический журнал. 1992. Т. 1, № 2. С. 209-219.

Андреев A. В. Экология роста птенцов гуменника Anser fabalis в Нижнеколымской тундре // Русский орнитологический журнал. 1993. Т. 2, № 4. С. 443-456.
Andreev $A$. $V$. Energy cost of incubation in the Arctic waders // Русский орнитологический журнал. 1994. T. 3, № 4. C. 291-302.

Andreev A. $V$. The Russian Far Northeast: the important bird areas and waterbird habitats // Conservation of migratory waterbirds and their wetlands habitats in the East-Asian-Australian flyway. Kushiro, 1994. P. 63-68.

Andreev A. V., Linden H. Winter energetics of the Capercaillie - a methodological approach // Ornis Fennica. 1994. No. 71. P. 33-42.

Andreev A. $V$. Winter nutrition of Willow Ptarmigan (Lagopus lagopus) : A trap that can affect population prosperity through the individual // Journal fur Ornitologie. 1994. Vol. 135, No. 3. S. 265.

Iwabuchi S., Sabano Y., Uemura S., Kurechi M., Andreev A., Kondratyev A., Takekawa J., Orthmyer D., Syroechkovsky E. Restoration Project of Snow Geese to East Asia // Annual Meeting of the Ornithological Society of Japan, 8-10 Oct. 1994. P. 132-145.

Iwabuchi S., Sabano Y., Kurechi M., Andreyev A. V., Kondratyev A. V., Baranyuk V. V., Syroechkovsky E. V., Litvin K. E., Takekawa J. Y., Orthmyer D. L. Transportation Method of Snow Geese Eggs // Proceedings of the Anatidae 2000 : An International Conference on the Conservation, Habitat Management and Wise Use of Ducks, Geese and Swans, 5-9 December 1994, Strasbourg, France / Birkan M.; Vessem J. van; Havet P.; Madsen J.; Trolliet B.; Moser M. (Editor); Birkan M. (Editor); Vessem J. van (Editor); Havet P. (Editor); Madsen J. (Editor); Trolliet B. (Editor); Moser M. (Editor). 1996. 1354 p. (Gibier Faune Sauvage - Game and Wildlife; No. 2, 3, Vol. 13.

Kurechi M., Gerasimov N. N., Andreev A. V., Kondratyev A. V., Takekawa J. Y., Orthmyer D. L. Migration of Anser fabalis and Anser albifrons in North-East Asia, with Special Reference to the Population Wintering in Japan // Proceedings of the Anatidae 2000 : An International Conference on the Conservation, Habitat Management and Wise Use of Ducks, Geese and Swans, 5-9 December 1994, Strasbourg, France / Birkan M.; Vessem J. van; Havet P.; Madsen J.; Trolliet B.; Moser M. (Editor); Birkan M. (Editor); Vessem J. van (Editor); Havet P. (Editor); Madsen J. (Editor); Trolliet B. (Editor); Moser M. (Editor). 1996. 1354 p. (Gibier Faune Sauvage - Game and Wildlife; No. 2, 3, Vol. 13.

Андреев А. В., Голубова Е. Ю. Новое обнаружение гнездования короткоклювого пыжика Brachyramphus brevirostris на побережье Охотского моря // Русский орнитологический журнал. 1995. Т. 4, № 1/2. С. 6364.

Andreev A. V. Bird fauna of Northeast Asia: A summary of unique biodiversity and priorities for conservation // Ibid. 1995. Vol. 137. P. 195-197.

Klaus S., Lieser M., Suchant R., Andreev A. V. Beitrag zur Kenntnis der Waldvegetation in der fernostlischen Taiga Russlands (Amur region) // Allgemeine Forstzeitschrift. 1995. Nr. 14. S. 744-748.

Kurechi M., Sabano Y., Iwabuchi S., Syroechkovsky E., Baranyuk V., Andreev A., Kondratyev A., Takekawa J., Milta N. Study on the restoration of Lesser Snow Goose to Northeast Asia using miniature satellite transmitter // The Telecommunication Advancement Foundation Research Report. 1995. No. 9. P. 518-541 [In Japanese].

Mollers F., Englander W., Klaus S., Andreev A. V. Ein Raufusshühn im dichten Wald - Variabilitat im 
Ausdrucksverhgalten // Journal für Ornitologie. 1995. Vol. 136, No. 3. S. 24-34.

Sabano Y., Uemura S., Kurechi M., Andreev A., Kondratyev A., Syroechkovsky E., Litvin K., Baranyuk V., Takekawa J., Orthmeyer D. Restoration of Lesser Snow Geese to east Asia, an International Conservation Project / The $8^{\text {th }}$ North American Arctic Goose Conference $\left(8^{\text {th }}\right.$ NAAG), 11-14 January 1995. Albuquerque, New Mexico, 1995. P. 58.

Shimada T., Uemura S., Kurechi M., Gerasimov N., Andreev A., Kondratyev A., Takekawa J., Orthmeyer D. Migration of Anser fabalis and Anser albifrons in northeast Asia, with special reference to the population wintering in Japan / The $8^{\text {th }}$ North American Arctic Goose Conference ( ${ }^{\text {th }}$ NAAG), 11-14 January 1995, Albuquerque. New Mexico, 1995. P. 59.

Swenson J., Andreev A. V., Drovetski S. V. Factors shaping winter social organization in Hazel Grouse Bonasa bonasia: A comparative study in the eastern and western Palearctic // Journal of Avian Biology. 1995. No. 26. P. 4-12.

Zink R., Rohwer S., Andreev A. V., Dittmann D. TransBeringia comparisons of mitochondrial DNA differentiation in birds // The Condor. 1995. Vol. 97, Issue 3. P. 639-649.

Андреев А. В., Кондратьев А. В. Новый случай гнездования малого песочника на Чукотке // Информационные материалы Рабочей группы по куликам. Москва, 1996. № 9. С. 34.

Madsen J., Reed A., Andreev A. Status and trends of geese (Anser sp., Branta sp.) in the world: A review, updating and evaluation // Gibier Faune Savage. 1996. Vol. 13. P. 337-354.

Андреев A. В. Берингия и история голарктических авифаун // Вестник ДВО РАН. 1997. № 2. С. 23-38.

Андреев A. B. Мониторинг гусей Северной Азии // Видовое разнообразие и состояние популяций околоводных птиц Северо-Востока Азии : сб. науч. тр. Магадан : СВНЦ ДВО РАН, 1997. С. 5-36.

Андреев A. В. Бородатая неясыть Strix nebulosa // Красная книга севера Дальнего Востока России / под ред. А. Я. Кондратьева. Москва : Пента, 1998. С. 205206.

Андреев A. В. Бурая оляпка Cinclus pallasi // Красная книга севера Дальнего Востока России / под ред. А. Я. Кондратьева. Москва : Пента, 1998. С. 207-209.

Андреев A. В. Длиннохвостая, или уральская неясыть Strix uralensis // Красная книга севера Дальнего Востока России / под ред. А. Я. Кондратьева. Москва : Пента, 1998. С. 203-205.

Андреев A. B. Кречет Falco gyrfalco // Красная книга севера Дальнего Востока России / под ред. А. Я. Кондратьева. Москва : Пента, 1998. С. 141-142.

Андреев A. B. Мохноногий сыч Aegolius funereus // Красная книга севера Дальнего Востока России / под ред. А. Я. Кондратьева. Москва : Пента, 1998. С. 200202.

Андреев А. В. Рыбный филин Ketupa blakistoni // Красная книга севера Дальнего Востока России / под ред. А. Я. Кондратьева. Москва : Пента, 1998. С. 199200.

Андреев A. В. Сапсан Falco peregrinus // Красная книга севера Дальнего Востока России / под ред. А. Я. Кондратьева. Москва : Пента, 1998. С. 143-144.

Андреев A. В. Сибирская чечевица Carpodacus roseus // Красная книга севера Дальнего Востока Рос- сии / под ред. А. Я. Кондратьева. Москва : Пента, 1998. С. 210-211.

Андреев A. В. Стерх Grus leucogeranus // Красная книга севера Дальнего Востока России / под ред. А. Я. Кондратьева. Москва : Пента, 1998. С. 146-147.

Андреев A. B. Тундровый гуменник Anser fabalis serrirostris // Красная книга севера Дальнего Востока России / под ред. А. Я. Кондратьева. Москва : Пента, 1998. С. 111-112.

Андреев А. В. Филин Виbo bubo // Красная книга севера Дальнего Востока России / под ред. А. Я. Кондратьева. Москва : Пента, 1998. С. 197-198.

Andreev A. V., Hafner F. Zur Biologie des Sichelhuhn Falcipennis falcipennis // Limicola. 1998. Band 12. Heft 3. S. 105-135.

Hafner F., Andreev A. V. Das Sichelhuhn. Klagenfurt; St. Petersburg, 1998. 118 p.

Андреев A. В. Белая куропатка на севере Азии: неустойчивость популяций, порождаемая аутэкологическим совершенством // Наука на Северо-Востоке России : (К 275-летию Рос. акад. наук). Магадан : СВНЦ ДВО РАН, 1999. С. 166-176.

Андреев А. В., Зубакин В. А., Свиридова Т. В., Реймерс $A$. Н. Ключевые орнитологические территории России: Сибирь и Дальний Восток : метод. разраб. Москва : Союз охраны птиц России, 1999. 40 с.

Andreev $A$. $V$. Ecological energetics and survival of birds in extreme environments // Ostrich. 1999. Vol. 70, No. 1 (XXII IOC plenary lectures). P. 13-22.

Andreev A. V. Zwischen Eissumpf und Packeis - das Leben der Rosenmowe Rhodostethia rosea // Limicola. 1999. Band 13. Heft 1. S. 1-22.

Андреев А. В. Ключевые орнитологические территории Охотско-Колымского края (Магаданская область) // Инвентаризация, мониторинг и охрана ключевых территорий России / Союз охраны птиц России, Программа «Ключевые орнитологические территории России». Москва : Союз охраны птиц России, 2000. Вып. 2. С. 11-15.

Андреев A. В. Проекты азиатского совета BirdLife на востоке Азии // Инвентаризация, мониторинг и охрана ключевых территорий России / Союз охраны птиц России, Программа «Ключевые орнитологические территории России». Москва : Союз охраны птиц России, 2000. Вып. 2. С. 62-64.

Водно-болотные угодья России. Т. 4. Водно-болотные угодья Северо-Востока России / сост. А. В. Андреев. Moscow : Wetlands International, 2001. 296 c. Andreev A. V., Kondratyev A. V. Birds of the KoniPiagyn and Malkachan areas // Biodiversity and ecological status along the Northern coast of the Sea of Okhotsk. Vladivostok, 2001. P. 87-122.

Andreev A. V. Die historische und aktuelle Bedeutung Beringias für die holarktische Avifauna // Limicola. 2001. Band 15. Heft 6. S. 313-348.

Andreev A. V., Hafner F., Klaus S., Gossow H. Displaying behaviour and mating system in the Siberian Spruce Grouse (Falcipennis falcipennis Hartlaub, 1855) // Journal für Ornithologie. 2001. Band 142. S. 404-424.

Holtmann B., Englander W., Kondratyev A. V., Andreev A. V., Bergmann H.-H., Fock S., Gunther J., Persigehl M., Potthof Ch., Saur B., Trentmann O. On the ecology of Harlequin ducks Histrionicus histrionicus in the Siberian Far East during summer // Biodiversity and Eco- 
logical Status along the Northern Coast of the Sea of Okhotsk. Vladivostok, 2001. P. 146-157.

Klaus S., Andreev A. V. Raufusshuhn als Landschaftsgartner: Steinauerhuhner in Nordostsibirien // Der Falke. 2001. Band 48. S. 132-137.

Threatened birds of Asia: The BirdLife International Red Data Book / Ed. by N. Collar, A. V. Andreev, S. Chan, M. J. Crosby, S. Subramanaya, J. A. Tobias. Cambridge, 2001. 3038 р. (Общее редактирование и написание очерков по 12 видам).

Андреев А. В., Голубова Е. Ю., Китайский А. С. Колонии морских птиц острова Талан: разрешающая сила постоянства // Природа. 2002. № 10. С. 41-50.

Lieser M., Andreev A., Klaus S. Larchenwalder im Raum Magadan - Ostsibirien // Forstarchiv. 2002. Band 73. S. 11-14.

Andreev A. V. Steinauerhahn: ein gartener in Sibirien winter // Limicola. 2003. Band 17. Heft 3. S. 1-22.

Klaus S., Andreev A. V. Falcipennis falcipennis (Hartlaub 1855) Sichelhuhn // Atlas der Verbreitung palaearktischer Vögel. Berlin, 2003. Band 20. S. 1-6.

Klaus S., Mertens J., Andreev A. V., Sun Y.-H. Bonasa bonasia (Linnaeus, 1758) // Atlas der Verbreitung palaearktischer Vögel. Berlin, 2003. Band 20. S. 1-15.

Wetlands in Northeastern Russia. Vol. 4. Wetlands in Northeastern Russia / Compiled by A.V. Andreev. Moscow : Wetlands International, 2004. 198 p.

Андреев А. В. Ключевые орнитологические территории бассейна Охотского моря // Вестник СевероВосточного научного центра ДВО РАН. 2005. № 1. C. 57-77.

Андреев А. В. Птицы бассейна Тауйской губы и прилежащих участков Северного Приохотья // Биоразнообразие бассейна Тауйской губы. Владивосток : Дальнаука, 2005. С. 579-627.

Andreev A. $V$. Nesting biology of Asian Spruce Grouse / X Int. Symposium on Grouse, 26-30 Sep. 2005. Luchon, 2005. P. 3.

Ely C. R., Fox A. D., Alisauskas R. T., Andreev A., Bromley R. G., Degtyarev A. G., Ebbinge B., Gurtovaya E. N., Kerbes R., Kondratyev A. V., Kostin I., Krechmar A. V., Litvin K. E., Myabayashi Y., Mooij J. H., Oates R. M., Orthmeyer D. L., Sabano Y., Simpson S. G., Solovieva D. V., Spindler M. A., Syroechkovsky Ye. V., Takekava J. Y., Walsh A. Circumpolar variation in morphological characteristics of Greater White-fronted Geese Anser albifrons // Bird Study. 2005. Vol. 52. P. 104-119.

Андреев $A$. В. Между вечной мерзлотой и дрейфующими льдами: розовая чайка на колымских гнездовьях // Бутурлинский сборник : Материалы II международных Бутурлинских чтений, 21.09-24.09.2005 г. Ульяновск, 2006. С. 79-99.

Андреев A. В. Рыбный филин (Ketupa blakisoni) на северо-восточной окраине ареала // Геология, география и биологическое разнообразие Северо-Востока России : Материалы Дальневост. регион. конф., посвящ. памяти А. П. Васьковского и в честь его 95летия (Магадан, 28-30 ноября 2006 г.). Магадан : СВНЦ ДВО РАН, 2006. С. 309-312.

Наземные позвоночные Северо-Востока России: аннотир. каталог / А. В. Андреев, Н. Е. Докучаев, А. В. Кречмар, Ф. Б. Чернявский : 2-е изд., испр. и доп. Магадан : СВНЦ ДВО РАН, 2006. 315 с.

Андреев А. В. Вклад А. П. Васьковского в изучение биологического разнообразия и охрану природы
Северо-Востока Азии // Вестник Северо-Восточного научного центра ДВО РАН. 2007. № 1. С. 37-46.

Андреев $A$. B. Методы наземной и спутниковой пеленгации морских птиц // Методы и теоретические аспекты исследования морских птиц : Материалы $\mathrm{V}$ Всерос. школы по морской биологии (25-27 окт. 2006 г., г. Ростов-на-Дону). Ростов-на-Дону : ЮНЦ PAH, 2007. C. 41-46.

Андреев А. В., Ван-Пельт Т. Размещение и численность птиц в прибрежных водах зал. Шелихова, Охотское море // Вестник Северо-Восточного научного центра ДВО РАН. 2007. № 2. С. 4-12.

Andreev $A$. $V$. Species diversity and migration of birds over Northern Sea of Okhotsk // Recent trends of researches and conservation efforts on migratory birds : Proceed. of the International Symposium on Migratory Birds / Nature Park Migratory Birds Center, 20-22 April 2007. Seoul, Korea, 2007. P. 87-95.

Romanenko O. V., Andreev A. V. Fishes, birds, amphibians and mammals of the Bering Sea ecoregion // Shared Beringian Ecoregion Program, Nat. Park Service. Anchorage, 2007. P. 1-32.

Vertyankin V. V., Vladimirov V. A., Tyurneva O. Yu., Yakovlev Yu. M., Andreev A. V., Burkanov V. N. Sightings of Gray Whales (Eschrichtius robustus) offshore Eastern Kamchatka and in the Northern Sea of Okhotsk, 2006 / $59^{\text {th }}$ Annual Meeting of the International Whaling Commission. Anchorage, Alaska, 2007. P. 1-8.

Андреев А. В., Докучаев Н. Е., Грачев А. И., Кашин B. A. Млекопитающие // Красная книга Магаданской области. Редкие и находящиеся под угрозой исчезновения виды растений и животных. Магадан, 2008. С.187-222.

Андреев А. В., Дорогой И. В., Кречмар А. В. Птицы // Красная книга Магаданской области. Редкие и находящиеся под угрозой исчезновения виды растений и животных. Магадан, 2008. С. 93-184.

Андреев A. В. Гуси северо-восточной Азии: энергетика особей и динамика популяций // Казарка. 2009. № 12. С. 10-32.

Andreev A. V. The Blakiston's Fish Owl (Ketupa blakistoni) at north-eastern limits of its range // Osnabrücher Naturwissenschaftliche Mitteilungen. 2009. Band 35. S. 47-54.

Andreev A. V., Golubova E. Yu., Kharitonov S. P., Zubakin $V$. A. Number of seabirds on the Talan Island: Twenty-year trends $/ 36^{\text {th }}$ Annual Meeting of the Pacific Seabird Group, 22-25 February 2009. Hakodate, Hokkaido, Japan, 2009. P. 29.

Андреев А. В. Осенняя миграция большого песочника Calidris tenuirostris на Охотском побережье // Вестник Северо-Восточного научного центра ДВО РАН. 2010. № 3. С. 19-28.

Андреев А. В., Голубова Е. Ю., Зубаткин В. А., Харитонов С. П. Численность морских птиц в колониях озера Талан: 20-летний тренд // Вестник СевероВосточного научного центра ДВО РАН. 2010. № 2. C. 30-42.

Andreev A. V. Arctic Geese in Eastern Asia: Agriculture in the south triggers and steers population dynamics in the North // Goose Bulletin. 2010. No. 10. P. $18-30$.

Андреев A. B. Наземное и спутниковое радиопрослеживание в изучении птиц Северо-Восточной Азии // Дистанционные методы исследования в зоологии : Ма- 
териалы науч. конф. (Москва, 28-29 ноября 2011 г.). Москва : Товарищество науч. изданий КМК, 2011. С. 6.

Андреев А. В. Природные условия участков заповедника // Растительный и животный мир заповедника «Магаданский». Магадан : СВНЦ ДВО РАН, 2011. C. 6-46.

Андреев А. В., Кречмар А. В., Утехина И. Г. Птицы // Растительный и животный мир заповедника «Магаданский». Магадан : СВНЦ ДВО РАН, 2011. C. $129-155$.

Андреев A. В. Распределение и численность короткоклювого (Brachyramphus brevirostris) и длинноклювого (B. pedrix) пыжиков вдоль северного побережья Охотского моря // Геология, география, биологическое разнообразие и ресурсы Северо-Востока России : Материалы Дальневост. регион. конф., посвящ. памяти А. П. Васьковского и в честь его 100-летия (Магадан, 20-24 ноября 2011 г.). Магадан : СВНЦ ДВО PAH, 2011. C. 109.

Andreev A. V. Die Insel Talan - Hohburg der Seevögel im Okhotskischer Meer // Limicola. 2011. Band 25. S. 195-231.

Andreev A., Hafner F. Winter biology of the Siberian Grouse Falcipennis falcipennis // Ornithological Science. 2011. Vol. 10, No. 2. P. 101-111.

Artyukhin Yu. B., Vyatkin P. S., Andreev A. V., Konyukhov N. B., VanPelt T. I. Status of the Kittlitz's Murrelet Brachyramphus brevirostris in Russia // Marine Ornithology. 2011. Vol. 39, No. 1. P. 23-33.

Андреев A. B. Берингийская орнитология: на пути к новому синтезу // Вестник Северо-Восточного научного центра ДВО РАН. 2012. № 3. С. 100-110.

Андреев А. В., Харитонов С. П., Слепцов Ю. А. Колонии морских птиц острова Ионы (Охотское море) // Зоологический журнал. 2012. № 7. С. 843-855.

Андреев А. В. Птицы береговой полосы полуострова Тайгонос (Гижигинская губа, Охотское море) // Вестник Северо-Восточного научного центра ДВО РАН. 2012. № 1. С. 20-32.

Klaus K.-H., Schindlatz S., Andreev A. V., Bergmann $H$. $-H$. Territorial behaviour of the Mongolian Black-billed Capercaillie Tetrao urogalloides stegmanni // Grouse News. 2012. No. 44. P. 15-20.

Андреев А. В., Слепц̧ов Ю. А. Материалы к изучению островных биот Тауйской губы: биотопическая структура и фауна птиц о. Спафарьева // Вестник Северо-Восточного научного центра ДВО РАН. 2013. № 4. C. 82-89.

Андреев А. В. Эталоны природы Охотско-Колымского края. Магадан : СВНЦ ДВО РАН, 2013. 322 с.

Андреев А. В., Кондратьев А. Я., Потапов Е. Р. Орнитофауна Нижнеколымских тундр: многолетняя динамика на фоне климатических перемен. Сообщение 1. Динамика состава нижнеколымской орнитофауны в XX в. и первом десятилетии XXI в. // Вестник Северо-Восточного научного центра ДВО РАН. 2015. № 1. C. 49-59.

Андреев А. В., Кондратьев А. Я., Потапов Е. Р. Орнитофауна Нижнеколымских тундр: многолетняя динамика на фоне климатических перемен. Сообщение 2. Статус, распространение и численность индикаторных видов // Вестник Северо-Восточного научного центра ДВО РАН. 2015. № 2. С. 57-68.

Андреев A. B. Репродуктивная биология каменного глухаря Tetrao urogalloides в Колымском нагорье: сезон токования и предгнездовой период // Вестник Северо-Восточного научного центра ДВО РАН. 2015. № 3. С. 49-60.

Боркин Л. Я., Андреев А. В. Арки: путешествие в забытое княжество Гималайских предгорий // Троицкий вариант - Наука. 2015. № 12 (181). 16 июня. C. $12-13$.

Боркин Л. Я., Андреев А. В. Буддийский праздник в Сани (Занскар) // Троицкий вариант - Наука. 2015. № 19 (188). 22 сентября. С. 8-9.

Боркин Л. Я., Андреев А. В. Бывшее княжество Зангла: краткий визит в прошлое вниз по реке Зан скар // Троицкий вариант - Наука. 2015. № 22 (191). 3 ноября. С. 10-11.

Боркин Л. Я., Андреев А. В. В гостях у гималайских ариев // Троицкий вариант - Наука. 2015. № 16 (185). 11 августа. С. 8-9.

Боркин Л. Я., Андреев А. В. В озерном краю Восточного Ладака // Троицкий вариант - Наука. 2015. № 15 (184). 28 июля. С. 8-9.

Боркин Л. Я., Андреев А. В. За пределами Больших Гималаев: дорога в Занскар и обратно // Троицкий вариант - Наука. 2015. № 25 (194). 22 декабря. С. 10-11.

Боркин Л. Я., Андреев А. В. Занскар: страна, где собираются феи // Троицкий вариант - Наука. 2015. № 24 (193). 8 декабря. С. 10-11.

Боркин Л. Я., Андреев А. В. Меняем план экспедиции: диктат обстоятельств // Троицкий вариант - Наука. 2015. № 13(182). 30 июня. С. 8-9.

Боркин Л. Я., Андреев А. В. Путешествие в незнакомую страну: от Инда вверх по реке Занскар // Троицкий вариант - Наука. 2015. № 21 (190). 20 октября. C. 8-9.

Ludwig T., Andreev A. V., Siano R. Auswirkungen von Kahlschlagen auf das Sichelhuhn Falcipennis falcipennis: erste Ergebnisse zweiter Forschungsreisen in die Okhotskische Taiga in Fernost-Russland // Vogelwarte. 2015. Nr. 53. S. 368-369.

Андреев А. В. Заливы Бабушкина и Кекурный // Морские орнитологические территории Дальнего Востока России. Москва : РОСИП, 2016. С. 81-83.

Андреев А. В. Зимние ночевки буроголовой гаички Parus montanus в приохотской тайге // Вестник Северо-Восточного научного центра ДВО РАН. 2016. № 4. C. 89-94.

Андреев А. В. Остров Ионы // Морские орнитологические территории Дальнего Востока России. Москва : РОСИП, 2016. С. 87-89.

Андреев А. В. Остров Талан // Морские орнитологические территории Дальнего Востока России. Москва : РОСИП, 2016. С. 84-86.

Андреев А. В. Острова Халпили и бухта Имповеем // Морские орнитологические территории Дальнего Востока России. Москва : РОСИП, 2016. С. 7577.

Андреев A. B. Репродуктивная биология каменного глухаря Tetrao urogalloides в Колымском нагорье: период гнездования // Вестник Северо-Восточного научного центраДВО РАН. 2016. № 2. С. 64-76.

Андреев А. В. Шантарские острова // Морские орнитологические территории Дальнего Востока России. Москва : РОСИП, 2016. С. 90-92.

Андреев А. В. Ямские острова // Морские орнитологические территории Дальнего Востока России. Москва : РОСИП, 2016. С. 78-80. 
Gilg O., Andreev A., Aebischer A., Kondratyev A., Sokolov A., Dixon A. Satellite tracking of Ross's Gull Rodostethia rosea in the Arctic ocean // Journal of Ornithology. 2016. Vol. 157, No. 1. P. 249-253.

Андреев A. В. Каменный глухарь Tetrao urogalloides Midd. в Колымском нагорье: половой диморфизм вида и особенности биологии разнополых птиц в зимний период // Вестник Северо-Восточного научного центра ДВО РАН. 2017. № 2. С. 82-94.

Андреев А. В. Птицы Западных Гималаев (по итогам экспедиций Санкт-Петербургского союза ученых, 2011-2015) // Российские гималайские исследования: вчера, сегодня, завтра : сб. науч. статей / под ред. Л. Я. Боркина. Санкт-Петербург : Европейский Дом, 2017. C. $145-151$.

Боркин Л. Я., Андреев А. В., Ганнибал Б. К., Литвинчук С. Н. Из Британской Индии в Фергану (1898): полевые наблюдения и сборы капитана Генерального штаба В. Ф. Новицкого в Кашмире и Ладаке // Российские гималайские исследования: вчера, сегодня, завтра : сб. науч. статей / под ред. Л. Я. Боркина. СанктПетербург : Европейский Дом, 2017. С. 22-35.

Боркин Л. Я., Андреев А. В., Ганнибал Б. К., Литвинчук С. Н., Сквориов В. В., Скоринов Д. В. ЗападноГималайский проект Санкт-Петербургского союза ученых // Российские гималайские исследования: вчера, сегодня, завтра : сб. науч. статей / под ред. Л. Я. Боркина. Санкт-Петербург : Европейский Дом, 2017. С. 36-45.

Pshenichnikova O. S., Klenova A. V., Sorokin P. A., Konyukhov N. B., Andreev A. V., Kharitonov S. P., Zubakin V. A., Artukhin Yu. B., Schacter C. R. Population differentiation in whiskered auklets Aethia pygmaea: do diurnal and nocturnal colonies differ in genetics, morphometry and acoustics? // Journal of Avian Biology. 2017. Vol. 48. P. 1047-1061.

Андреев A. В. Распространение и численность азиатского длинноклювого пыжика Brachyramphus perdix (Pallas, 1811) на северном побережье Охотского моря // Вестник Северо-Восточного научного центра ДВО РАН. 2018. № 3. С. 61-71.

Андреев А. В., Голубова Е. Ю. Многолетняя динамика численности и успех размножения большой конюги на острове Талан (Охотское море) / Первый Всероссийский орнитологический конгресс (г. Тверь,
29 января - 4 февраля 2018 г.) : тез. докл. / ред. А. Б. Поповкина, С. П. Харитонов. Тверь, 2018. С. 7-8.

Андреев А. В., Голубова Е. Ю. Планктоноядные чистиковые птицы о. Талан: Состояние гнездовий и перестройка прибрежной экосистемы Тауйской губы XXI в. / Международная научная конференция «Биологические проблемы Севера». Магадан, Россия, 1822 сентября 2018 г. : сб. аннотаций. Магадан : ИБПС ДВО РАН, 2018. С. 4.

Klaus S., Andreev A. V., Lieser M., Suchant R. Sichel-, Hasel- und Steinauerhuhn - Taigavögel im Fernen Osten Russlands // Der Ornithologische Beobachter. 2018. Band 115. Heft 3. S. 291-304.

Андреев $A$. B. Гнездовая биология азиатской дикуши Falcipennis falcipennis Hartlaub, 1855 в низкогорной части ареала // Вестник Северо-Восточного научного центра ДВО РАН. 2019. № 4. С. 83-94.

Андреев А. В., Голубова Е. Ю. Многолетняя динамика численности и успеха размножения большой конюги Aethia cristatella Pallas, 1769 на острове Талан (Охотское море) // Вестник ТвГУ. Сер. Биология и экология. 2019. № 1 (53). С. 15-30.

Боркин Л. Я., Андреев А. В. , Вершинин В. Л., Вершинина С. Д., Винарский М. В., Лопатина Е. В., Неупокоева Н. И. Непало-Тибетская мультидисциплинарная экспедиция Санкт-Петербургского союза ученых (лето 2018) // Биота и среда заповедных территорий. 2019. № 3. С. 124-137.

Klaus S., Andreev A. V., Schroeder V. A., Unger C., Sickle-shaped primaries and tail feathers involved in sound production in Siberian Grouse Falcipennis falcipennis Hartlaub, 1855 // Ornithologischer Anzeiger. Anz. 2019. P. 48-53.

Андреев А. В., Слободин С. Б., Хаменкова Е. В. Беспощадное освоение Колымы, последний рубеж южная часть хребта Черского // Природа. 2020. № 6. C. $32-45$.

Боркин Л. Я., Андреев А. В., Вершинин В. Л., Вершинина С. Д., Винарский М. В., Лопатина Е. Б., Неупокоева Н. И. Комплексная экспедиция СанктПетербургского союза ученых в Гархвальские Гималаи, Индия (2019): некоторые предварительные итоги // Биота и среда заповедных территорий. 2021. № 1. C. 106-145.

\title{
ALEXANDER ANDREEV: HIS RESEARCH AND ORGANIZATIONAL ROLE AND SCIENTIFIC HERITAGE IN THE ORNITHOLOGICAL RESEARCH AND NATURE CONSERVATION OF THE NORTH-EAST ASIA
}

\author{
A. V. Kondratyev, E. V. Khamenkova \\ Institute of Biological Problems of the North, FEB RAS, Magadan
}

The authors analyze the scientific and organizational activities of A. V. Andreev as a leader of ornithological research in Russia's North-East as well as his personal contribution in organization and development of nature conservation. The article is illustrated with previously unpublished photographs and presents the reference list of A. V. Andreyev major scientific publications since 1971. 